\title{
34. GEOCHEMISTRY OF SEDIMENTS AND INTERSTITIAL WATERS FROM OKI RIDGE AND KITA-YAMATO TROUGH, JAPAN SEA ${ }^{1}$
}

\author{
Anne A. Sturz, ${ }^{2}$ Barry B. Hanan, ${ }^{3}$ and Guy Emanuele ${ }^{2}$
}

\begin{abstract}
Interstitial waters in sediments below 400 (Site 798) and 435 meters below seafloor (Site 799) have chloride concentrations of 516-527 and 501-515 mM, respectively, lower than the $540 \mathrm{mM}$ of the modern-day Japan Sea. The chemical composition of interstitial waters, bulk sediments, clay-size sediment fraction, and carbonate nodules from Oki Ridge (Site 798) and Kita-Yamato Trough (Site 799), Japan Sea, reflect in-situ diagenetic processes superimposed on geochemical signals that may indicate freshening of Miocene local marginal basin waters. Interstitial waters at both sites exhibit changes in chemical composition which coincide with the occurrence of low-porosity and high-bulk density layers composed of dolomite and opal-CT, which impede diffusive communication with the overlying interstitial waters. Based on interstitial water stable isotope evidence and mass-balance calculations of chloride dilution, diagenetic reactions that involve the release of structural bound water from opal-A and/or clay minerals contribute to the observed geochemical signals, but cannot account for all the measured chloride dilution.
\end{abstract}

\section{INTRODUCTION}

The Japan Sea is a backarc basin formed by multiaxial rifting in a continental arc setting (Ludwig et al., 1975; Gnibidenko, 1979; Ingle, $1975,1990)$. Initial rifting occurred in the earliest Miocene, 18-20 Ma (Ingle, 1975, 1990; Kaneoka, 1990). Within the marginal sea, structural highs with water depths on the order of 500-m separate basins of oceanic water depths ( $>3000 \mathrm{~m}$ ) (Fig. 1). The basin basement rocks are basaltic (Ingle, Suyehiro, von Breymann, et al., 1990). At one structural high, Oki Ridge, basement is inferred, from dredged rock samples, geophysical data, and extrapolation from terrestrial outcrops, to be continental rocks of granitic composition (Ingle et al., 1990; Tamaki, 1988). Based on geophysical data, the Kita-Yamato Trough is thought to be a failed spreading rift (Tamaki, 1988).

The modern Japan Sea is isolated from communication with open Pacific deep and intermediate water masses by shallow $(<150 \mathrm{~m})$ sills. Warm, saline Pacific surface water enters the Japan Sea from the south via the Tsushima Strait. Cold surface water enters the Japan Sea from the north via the Korean-Liman current (Ingle, 1975). Severe winter cooling and freezing of surface waters in the northern Japan Sea promote vigorous thermohaline circulation. The water column is well mixed, with uniform salinity $(34 \mathrm{~g} / \mathrm{kg})$ and dissolved oxygen $(112 \mathrm{mM} / \mathrm{L})$ depth profiles (Ingle, 1975; Matoba, 1984).

Based on biostratigraphic evidence observed during Ocean Drilling Program (ODP) Legs 127 and 128, the Japan Sea region has experienced both periodic isolation and open exchange with the Pacific Ocean (Tamaki, Pisciotto, Allan, et al., 1990; Ingle, Suyehiro, von Breymann, et al., 1990). Many repetitions of light and dark sediment cycles indicate that the Japan Sea has experienced times of well-ventilated bottom water alternating with times of stable stratified water column (Ingle, Suyehiro, von Breymann, et al., 1990; also see Follmi et al., this volume)

This paper reports the results of shipboard and shore-based analysis of interstitial water, bulk and clay-size-fraction sediment, and carbonate nodules from Oki Ridge (Site 798) and Kita-Yamato Trough (Site 799), drilled during Leg 128. The objective of this study is to interpret observed anomalies in the dissolved chloride distribution by examining interstitial water strontium, oxygen, and hydrogen

Pisciotto, K. A., Ingle, J. C., Jr., von Breymann, M. T., Barron, J., et al., 1992. Proc. ODP, Sci. Results, 127/128, Pt. 1: College Station, TX (Ocean Drilling Program).

Scripps Institution of Oceanography, La Jolla, CA 92093, U.S.A.

Baylor Brooks Institute of Isotope Geology, San Diego State University, San Diego, CA 92182, U.S.A. isotopic composition and changes in bulk and clay-size-fraction sediment chemical and mineralogical composition. Interstitial waters in sediments below $400 \mathrm{~m}$ (Site 798) and $435 \mathrm{~m}$ (Site 799) have chloride concentrations of 516-527 and 501-515 mM, respectively, lower than the $540 \mathrm{mM}$ of the modern-day Japan Sea.

Site 798 is located at Oki Ridge, a topographically isolated structural high in the southeastern Japan Sea (Fig. 1). The primary site objective was the recovery of a paleoceanographic reference section. Drilling at Site 798 recovered a sequence of Pliocene-Pleistocene cyclic sediments that record major variations in productivity, dissolved oxygen, deposition of terrigenous clays, and explosive volcanism (as abundant ash layers) within the Japan Sea (Ingle et al., 1990; Ingle, Suyehiro, von Breymann, et al., 1990). Basement was not reached at this site.

Site 799 lies in Kita-Yamato Trough (Fig. 1). One objective of this site was the recovery of a section typical of volcanogenic massive sulfide deposition related to rifting in a backarc environment. Geophysical data and dredged samples of granite show that the Yamato Rise represents a continental fragment isolated during early Miocene seafloor spreading in the proto-Japan Sea (Ingle, 1975; Ludwig et al., 1975; Gnibidenko, 1979; Ingle et al., 1990). Spreading ceased at this site, leaving a failed rift graben that accumulated Miocene to Holocene sediments. Though massive sulfides were not encountered at Site 799, a 24-m-thick altered rhyolitic tuff breccia was recovered, correlative with similar rocks that host some of the Kuroko massive sulfide ores in northern Japan (Ingle, Suyehiro, von Breymann, et al., 1990; also see Scott et al., this volume). Common plant debris, biotite, and immature sands within turbidite units indicate that this site was near an island or continental shoreline within the complex of basins characterizing the early Miocene paleogeography of the Japan Sea (Ingle, Suyehiro, von Breymann, et al., 1990). Ash layers are abundant in sediments of Holocene to Miocene age. Ash layers are less abundant in sediments below $450 \mathrm{~m}$ below seafloor (mbsf) than in overlying layers, and none was observed between 470 and $560 \mathrm{mbsf}$ (Ingle, Suyehiro, von Breymann, et al., 1990; also see Pouclet et al., this volume).

\section{METHODS}

\section{Interstitial Water Sample Handling and Shipboard Techniques}

During Leg 128, interstitial waters were extracted according to standard shipboard procedures (Ingle, Suyehiro, von Breymann, et al., 1990). Shipboard measurements include $\mathrm{pH}$, alkalinity, salinity, 


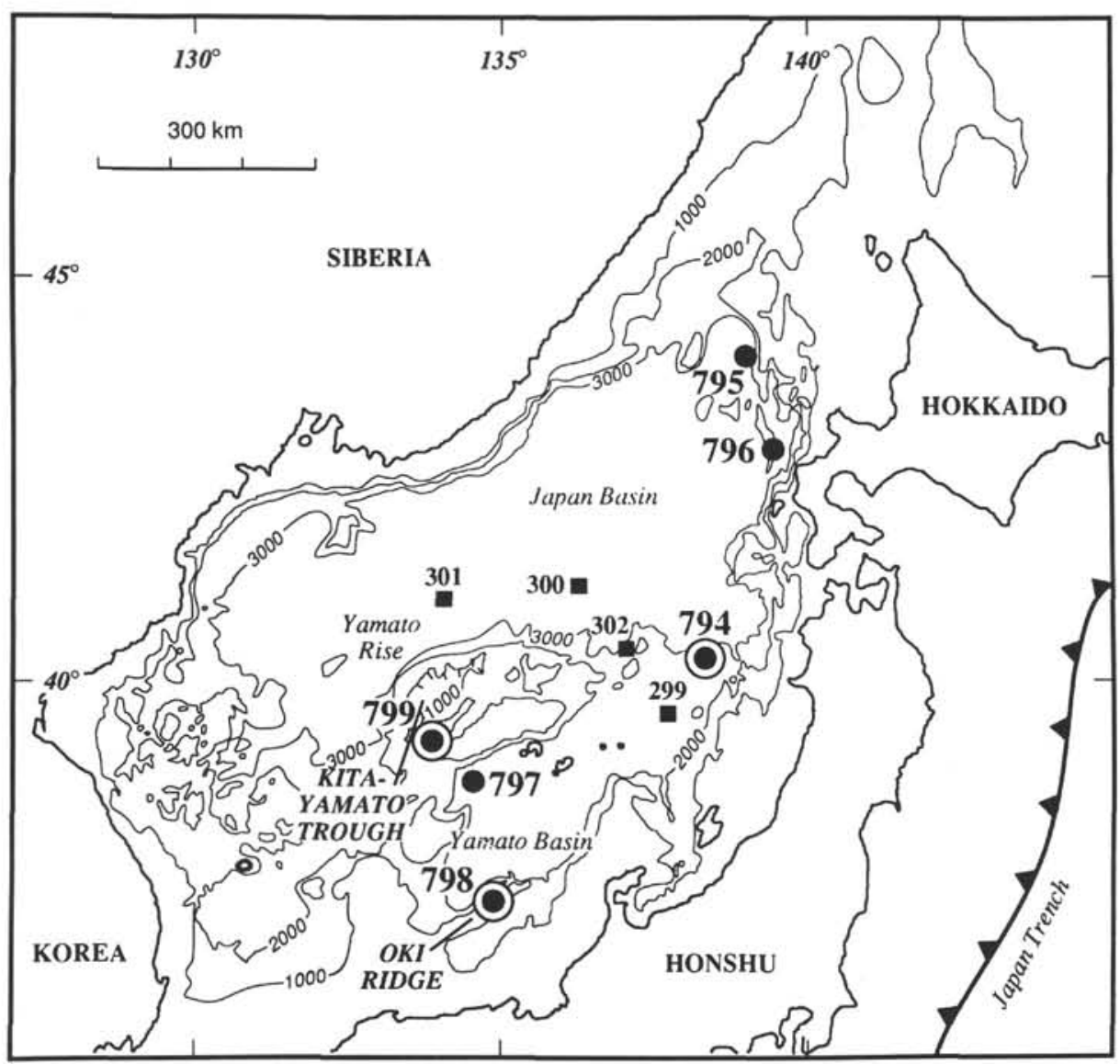

Figure 1. Location of drilled sites of ODP Legs 127 (dots) and 128 (circled dots) and DSDP Leg 31 (squares). Bathymetry is in meters.

chloride, sulfate, phosphate, ammonia, silica, magnesium, calcium, strontium, potassium, lithium, and manganese. Shipboard interstitial water analyses were performed using the procedures described by Gieskes and Peretsman (1986).

\section{Shore-based Sample Handling and Analytical Techniques}

Interstitial water oxygen, deuterium, and carbon isotopic ratios were determined by Global Geochemistry Corporation, Canoga Park, California, using standard mass spectrometric techniques. Carbon isotopes were determined using $\mathrm{CO}_{2}$. The data are shown in per mil enrichments of the isotopic ratios ${ }^{18} \mathrm{O} /{ }^{16} \mathrm{O}( \pm 0.1), \mathrm{D} / \mathrm{H}( \pm 2)$, and ${ }^{13} \mathrm{C} /{ }^{12} \mathrm{C}( \pm 0.07)$ relative to standard mean ocean water (SMOW).

The Sr isotope analyses were done in the laboratories of the Baylor Brooks Institute of Isotope Geology at San Diego State University. A $1-\mathrm{cm}^{3}$ aliquot of the interstitial water sample was taken from a shipboard-sealed vial and centrifuged to ensure that no solid materials were present. A $100-\mu \mathrm{L}$ aliquot was pipetted from the centrifuge tube into a PFA Teflon beaker and dried. The dried sample was dissolved in $2.5 \mathrm{M} \mathrm{HCl}$ and loaded into a Dowex 50W-8X,100-mesh cation exchange column (quartz, $\sim 4 \mathrm{~cm}^{3}$ ). The $\mathrm{Sr}$ fraction was eluted with $2.5 \mathrm{M} \mathrm{HCl}$ and evaporated to dryness. The separation process was repeated with a "cleanup" column (TFE, $0.75 \mathrm{~cm}^{3}$ ) loaded with Dowex 50W-8X, 200-400-mesh cation exchange resin. The dried sample was redissolved in a $2.5-\mu \mathrm{L}$ slurry of tantalum oxide/dilute phosphoric acid and loaded onto a single Re filament for isotopic analysis. Total $\mathrm{Sr}$ blanks were less than $200 \mathrm{pg}$ for the entire procedure and are negligible. The samples were analyzed on an AVCO $30.5-\mathrm{cm}$, single-focusing thermal ionization mass spectrometer. Typical ion beam intensities were $6 \times 10^{-10} \mathrm{Amp}{ }^{88} \mathrm{Sr}^{+}$. The ${ }^{87} \mathrm{Sr} /{ }^{86} \mathrm{Sr}$ ratios are normalized to ${ }^{87} \mathrm{Sr} /{ }^{86} \mathrm{Sr}=0.1194$ and referenced to NBS SRM987 = $0.71071 \pm 0.00026$ (2 standard errors, $n=3$ ). In-run precision for ${ }^{87} \mathrm{Sr} /{ }^{86} \mathrm{Sr}$ was in the range $0.007 \%$ to $0.019 \%$ ( 2 standard errors, $n>150$ ).

The clay-size sediment fraction was separated from six bulk-sediment samples by settling in double-deionized water. The mineralogy of the bulk solids was determined by petrographic microscopy and $\mathrm{X}$-ray diffractometry. Clay mineralogy, using the $<2-\mu \mathrm{m}$ size fraction, was determined by comparing the $(001)$ and $(060)$ reflections of air-dried, glycolated, and heat-treated $\left(325^{\circ} \mathrm{C}\right.$ and $\left.550^{\circ} \mathrm{C}\right)$ clay mineral diffraction patterns (Brindley and Brown, 1980).

Bulk sediments were air-dried with salts intact. Corrections for the salt content of air-dried bulk sediments are determined by measurement of dissolved chloride from $1 \mathrm{~g}$ of sediment stirred in $100-\mathrm{mL}$ double-distilled water, with corrections based on the ratio of salt relative to chloride. Bulk sediments and clay-size-fraction separates were prepared for analyses by lithium metaborate/hexaborate fluxed fusion at $1000^{\circ} \mathrm{C}$, followed by dissolution of the glass bead in $1 \mathrm{~N} \mathrm{HNO}_{3}$. Chemical analyses were performed on dissolved sediments by atomic absorption spectroscopy $(\mathrm{Ca}, \mathrm{Mg}, \mathrm{Na}, \mathrm{K}, \mathrm{Fe}, \mathrm{Cu}$, and $\mathrm{Zn})( \pm 3 \%)$ and colorimetric spectroscopy $(\mathrm{Si}, \mathrm{Al}$, and $\mathrm{Ti})( \pm 4 \%)$. Some trace elements ( $\mathrm{Co}$ and $\mathrm{Cr})( \pm 2 \%)$ were determined on bulksediment solids by neutron activation.

Carbonate nodules from three intervals (Cores 128-799A-51X, 128-799B-18R, and 128-799B-21R) were hand-picked from the bulk sediment. Each nodule was washed and ultrasonically treated to remove adhered clay particles. The nodules were then slightly crushed and hand-picked under an 8-power binocular microscope to separate clean carbonate fragments. One portion of each crushed, hand-picked 
carbonate nodule fragment was analyzed by X-ray diffraction to determine mineralogy. Another portion of each of the crushed fragments was weighed and dissolved in $10 \%$ ultrapure $\mathrm{HCl}$. Fe, $\mathrm{Mn}, \mathrm{Ca}$, and $\mathrm{Mg}$ concentrations $( \pm 3 \%)$ of the dissolved carbonates were measured by atomic absorption spectroscopy.

\section{RESULTS AND DISCUSSION}

\section{Interstitial Water}

Interstitial water chemical compositions within the upper $15 \mathrm{~m}$ of sediment at Site 798 and within the upper $45 \mathrm{~m}$ of sediment at Site 799 are dominated by early diagenetic processes related to sulfate reduction accompanying the early stages of organic matter decomposition (Tables 1 and 2; Fig. 2). Sulfate drops to nearly zero by $10 \mathrm{mbsf}$ at Site 798 and by 28 mbsf at Site 799 (Fig. 2). Variations in salinity largely reflect a net change in the sum of major dissolved ions. Decreasing salinity (Fig. 2) in the upper $13 \mathrm{~m}$ (from 34.5 to $33.7 \mathrm{~g} / \mathrm{kg}$ ) and upper $36 \mathrm{~m}$ (from 34.0 to $32.0 \mathrm{~g} / \mathrm{kg}$ ) at Sites 798 and 799 , respectively, reflects decreases in dissolved sulfate within the zone of intense sulfate reduction. Increasing salinity below the zone of intense sulfate utilization reflects the progressive addition of metabolites from the decomposition of organic matter. Organic matter degradation accounts for increases in alkalinity to $71 \mathrm{mM}$ at $149 \mathrm{mbsf}$ at Site 798 and to $42 \mathrm{mM}$ at $73 \mathrm{mbsf}$ at Site 799 (Fig. 2). Methanogenesis below the zone of sulfate depletion is indicated by a rapid rise in methane concentration, from $56 \mathrm{mg} / \mathrm{L}$ at $1.5 \mathrm{mbsf}$ to near $65,000 \mathrm{mg} / \mathrm{L}$ at 22.8 mbsf at Site 798 and from $14 \mathrm{mg} / \mathrm{L}$ at $25 \mathrm{mbsf}$ to near 155,000 $\mathrm{mg} / \mathrm{L}$ at $44 \mathrm{mbsf}$ at Site 799 (Ingle, Suyehiro, von Breymann, et al., 1990). Changes in dissolved manganese concentration in the upper $10 \mathrm{~m}$ at both sites (Fig. 2) may be related to redox-controlled manganese cycling in near-surface sediments associated with the zone of bacterially mediated sulfate utilization (also see von Breymann, this volume.) The release of phosphate during the early stages of diagenesis and organic matter decomposition is indicated by increases in dissolved phosphate concentrations, at 60 and 36 mbsf at Sites 798 and 799 , respectively (Fig. 2). Phosphate maxima overlie the zone of phosphate removal (to near zero by $300 \mathrm{mbsf}$ at both sites). Increases in dissolved ammonia with depth (Fig. 2) are also the consequence of organic matter decomposition.

Decreasing dissolved calcium concentrations that accompany increasing alkalinity suggest that inorganic carbonate is forming between near-surface sediments and 70 mbsf at Site 798 (Fig. 2). The decreasing dissolved calcium concentration from near surface to $220 \mathrm{mbsf}$ at Site 799 is less apparent. Well-formed carbonate rhombs are observed as shallow as 5 mbsf at Site 798 and 12.5 mbsf at Site 799 (Ingle, Suyehiro, von Breymann, et al., 1990). Steady increases in dissolved strontium concentration from the near surface to about $450 \mathrm{mbsf}$ (Fig. 2) may indicate the release of strontium to the interstitial water accompanying biogenic carbonate recrystallization. The strontium concentrations in interstitial waters below $450 \mathrm{~m}$ are variable, and indicate a generally decreasing trend below $450 \mathrm{~m}$. (Also see subsequent discussion of interstitial water dissolved strontium concentration and $\mathrm{Sr}$ isotope values.)

Chloride concentration remains nearly constant in interstitial waters from near surface to about $300 \mathrm{mbsf}$ (Fig. 2). Dissolved silica and potassium (Fig. 2) concentrations show a slight increase and decrease, respectively, whereas lithium and $\mathrm{pH}$ (Fig. 2) remain nearly constant above $300 \mathrm{mbsf}$. The increase in silica concentration is associated with biogenic silica dissolution and ash alteration.

Changes in interstitial water chemical composition at intermediate depths (below about 70 mbsf at Site 798 and below about $200 \mathrm{mbsf}$ at Site 799) indicate that sediment lithification, including dolomitization and the transformation from opal-A to opal-CT, are active processes. Evidence observed in interstitial water chemical compositions that support dolomitization includes magnesium removal and calcium release, and associated maxima in the $\mathrm{Mg} / \mathrm{Ca}$ molar ratios at 70 and 220 mbsf at Sites 798 and 799, respectively (Fig. 2). Dissolved silica and lithium concentrations increase below about $250 \mathrm{mbsf}$ at both sites, suggesting the dissolution of opal-A. The transition from opal-A to opal-CT is indicated by the onset of decreasing dissolved silica concentration in interstitial water below $370 \mathrm{mbsf}$ at Site 798 and at 380 mbsf at Site 799. It should also be noted that volcanic ash is abundant in the upper $450 \mathrm{~m}$ of sediment at Site 799 (Ingle, Suyehiro, von Breymann, et al., 1990). Changes in dissolved silica may be influenced by ash alteration.

Interstitial waters from the lowermost sediments sampled at both sites are marked by decreases in alkalinity, silica, potassium, and ammonia, increases in dissolved calcium, and variable to decreasing concentrations of salinity, chlorinity, and strontium. The changes in interstitial water chemistry, which are more distinct at Site 799 than at Site 798, coincide with low-porosity and high-bulk-density layers composed of dolomite and opal-CT (Ingle, Suyehiro, von Breymann, et al., 1990). These low-permeability layers below $450 \mathrm{mbsf}$ impede, to some extent, diffusive communication with the fluids of the overlying interval.

Strontium isotopic results from Site 799 are shown in Table 3 and Figure 3. In general, the ${ }^{87} \mathrm{Sr} /{ }^{86} \mathrm{Sr}$ ratios decrease with depth in a manner consistent with the natural variation of ${ }^{87} \mathrm{Sr} /{ }^{86} \mathrm{Sr}$ in the oceans through time. With the exception of Section 128-799B-7R-2 from Miocene sediments at $503 \mathrm{mbsf}$, the range in the Site 799 interstitial water values for ${ }^{87} \mathrm{Sr} /{ }^{86} \mathrm{Sr}(0.70897-0.70864)$ is within the range of reported values for the Miocene seawater record (Ingram and DePaolo, 1985; DePaolo, 1986; Hess et al., 1986; McKenzie et al., 1988). The ${ }^{87} \mathrm{Sr} /{ }^{86} \mathrm{Sr}$ for Section $128-799 \mathrm{~B}-7 \mathrm{R}-2$ is anomalously low, and falls outside of the established variation for Miocene seawater. The Sr concentration for Section 128-799B-7R-2 is anomalously low relative to the overall variation shown by the Site 799 interstitial waters. The $\mathrm{Sr}$ isotopic data for Section 128-799B-7R-2 suggest $\mathrm{Sr}$ exchange between interstitial Miocene seawater and material with lower ${ }^{87} \mathrm{Sr} /{ }^{86} \mathrm{Sr}$, such as volcanic ash $\left({ }^{87} \mathrm{Sr} /{ }^{86} \mathrm{Sr}=0.703-0.704\right)$. Volcanic ash is abundant in sediments recovered at Site 799 (Ingle, Suyehiro, von Breymann, et al., 1990). Though 198 individual ash layers were deposited during the Miocene through late Holocene, only 25 ash layers were recovered below $450 \mathrm{mbsf}$ at Site 799, and no ash layers were observed between 470 and 560 mbsf (Ingle, Suyehiro, von Breymann, et al., 1990; also see Pouclet et al., this volume).

Interstitial water oxygen, deuterium, and carbon isotopic ratios for Site 799 are given in Table 3 and isotopic distributions are shown in Figure 3. The carbon isotopic signature of these fluids (ranging from $-5 \%$ o to $-23 \%$ o) can be attributed to processes related to organic matter degradation. Oxygen and deuterium isotopic ratios show significant shifts toward lighter values (from $\delta^{18} \mathrm{O}$ of $-1.5 \%$ at $220 \mathrm{mbsf}$ to $-3.8 \%$ at $408 \mathrm{mbsf}$ and $\delta \mathrm{D}$ of $-3 \%$ at $220 \mathrm{mbsf}$ to -13 at $408 \mathrm{mbsf}$ ) in interstitial waters below the low-permeability layers.

There are several possible mechanisms that would explain the observed interstitial water compositional changes that mark these lowermost intervals. One mechanism is the preservation of connate brackish water below low-permeability units as a source of low-salinity fluids observed at both Sites 798 and 799. Eustatic changes associated with glacial/interglacial cycles and/or tectonic changes in the Japan Sea basin/ridge configuration may have isolated local basins from communication with the open ocean and allowed the freshening of basin waters (Ingle et al., 1990). Based on geophysical evidence, Tamaki (1988) suggested that the topographic highs (Yamato Rise) that flank Kita-Yamato Trough may have been at or above wave base and represent wave-cut platforms. Neogene freshwater sediments on the northeast flank of the Yamato Rise have been inferred from micropaleontological evidence (Burckle and Akiba, 1978). Common plant debris, biotite, and immature sands within turbidite units in units below 1010 mbsf indicate that Site 799, within Kita-Yamato Trough, was near an island or continental shoreline within the complex of basins characterizing the early Miocene paleogeography of the Japan Sea (Ingle et al., 1990; Ingle, Suyehiro, von Breymann, et al., 1990). This combined evidence allows one to postulate that the Kita-Yamato 
Table 1. Chemical composition of interstitial waters, Site 798, Oki Ridge.

\begin{tabular}{|c|c|c|c|c|c|c|c|c|c|c|c|c|c|c|}
\hline $\begin{array}{l}\text { Depth } \\
\text { (mbsf) }\end{array}$ & $\mathrm{pH}$ & $\begin{array}{c}\text { Alkalinity } \\
(\mathrm{mM})\end{array}$ & $\begin{array}{c}\text { Salinity } \\
(\mathrm{g} / \mathrm{kg})\end{array}$ & $\underset{(\mathrm{mM})}{\mathrm{Cl}}$ & $\begin{array}{c}\mathrm{SO}_{4} \\
(\mathrm{mM})\end{array}$ & $\begin{array}{l}\mathrm{PO}_{4} \\
(\mu \mathrm{M})\end{array}$ & $\begin{array}{l}\mathrm{NH}_{4} \\
(\mu \mathrm{M})\end{array}$ & $\begin{array}{l}\mathrm{SiO}_{2} \\
(\mu \mathrm{M})\end{array}$ & $\underset{(\mathrm{mM})}{\mathrm{Mg}}$ & $\underset{(\mathrm{mM})}{\mathrm{Ca}}$ & $\mathrm{Mg} / \mathrm{Ca}$ & $\underset{(\mu \mathrm{M})}{\mathrm{Sr}}$ & $\underset{(\mathrm{mM})}{\mathrm{K}}$ & $\begin{array}{c}\text { Mn } \\
(\mu \mathrm{M})\end{array}$ \\
\hline \multicolumn{15}{|c|}{ Hole $798 \mathrm{~A}$} \\
\hline 1.45 & 7.6 & 21.3 & 34.8 & 544 & & 96 & 580 & 663 & 50.4 & 8.22 & 6.1 & 112 & 12.0 & 10.8 \\
\hline 47.65 & 7.4 & 68.5 & 35.2 & 537 & & 257 & 7940 & 818 & 57.6 & 4.44 & 13.0 & 133 & 13.0 & 2.2 \\
\hline 79.25 & 7.3 & 74.0 & 35.6 & 536 & & 234 & 8860 & 898 & 55.9 & 4.48 & 12.5 & 136 & 14.0 & 5.9 \\
\hline 109.02 & 7.5 & 74.6 & 35.5 & 539 & & 232 & 8800 & 974 & 53.0 & 5.35 & 9.9 & 160 & 12.0 & 7.4 \\
\hline 137.15 & 7.4 & 67.1 & 35.0 & 539 & & 175 & 8580 & 1039 & 47.2 & 4.64 & 10.2 & 170 & 14.0 & \\
\hline
\end{tabular}

Hole 798B

\begin{tabular}{|c|c|c|c|c|c|c|c|c|c|c|c|c|c|c|}
\hline 1.25 & 7.7 & 7.3 & 34.5 & 546 & 25.1 & 40 & 380 & 620 & 51.8 & 10.18 & 5.1 & 132 & 13.6 & 28.0 \\
\hline 1.85 & 7.5 & 9.4 & 34.6 & 548 & 24.4 & 55 & 492 & 648 & 50.9 & 9.83 & 5.2 & 117 & 12.8 & 22.7 \\
\hline 2.77 & 7.5 & 13.6 & 34.5 & 543 & 21.5 & 64 & 667 & 648 & 49.5 & 9.20 & 5.4 & 105 & 13.0 & 11.5 \\
\hline 4.00 & 7.7 & 18.0 & 34.5 & 546 & 17.7 & 86 & 933 & 676 & 49.8 & 7.56 & 6.6 & 109 & 13.0 & 6.7 \\
\hline 5.75 & 7.5 & 25.8 & 34.6 & 543 & 12.0 & 87 & 2077 & 741 & 49.8 & 8.48 & 5.9 & 120 & 13.5 & 6.4 \\
\hline 9.85 & 7.6 & 40.9 & 33.8 & 550 & 0.6 & 56 & 2560 & 769 & 49.6 & 5.86 & 8.4 & 117 & 16.3 & \\
\hline 12.85 & 7.6 & 43.3 & 33.7 & 547 & 0.3 & 68 & 3340 & 778 & 50.1 & 5.67 & 8.8 & 113 & 15.8 & 3.9 \\
\hline 23.75 & 7.5 & 53.0 & 34.0 & 540 & 0.1 & 279 & 5230 & 808 & 52.8 & 5.24 & 10.1 & 120 & 13.4 & 4.2 \\
\hline 36.96 & 7.4 & 61.7 & 34.7 & 535 & 0 & 280 & 6630 & 825 & 54.9 & 4.61 & 11.9 & 113 & 14.5 & 3.9 \\
\hline 42.70 & 7.4 & 63.7 & 35.0 & 535 & 0 & 234 & 7510 & 791 & 55.4 & 4.12 & 13.4 & 128 & 16.5 & 2.4 \\
\hline 50.59 & 7.4 & 67.5 & 35.4 & 538 & 0.3 & 268 & 7340 & 860 & 56.4 & 4.25 & 13.3 & 136 & 13.6 & \\
\hline 59.98 & 7.3 & 69.2 & 34.3 & 543 & 0.1 & 286 & 7840 & 858 & 56.4 & 4.52 & 12.5 & 136 & 15.5 & 4.2 \\
\hline 70.67 & 7.4 & 69.2 & 35.5 & 541 & & & 7570 & 813 & 55.3 & 3.36 & 16.5 & 120 & 15.2 & 4.6 \\
\hline 78.57 & 7.4 & 72.3 & 35.6 & 538 & 0.4 & 249 & 7850 & 897 & 54.3 & 4.26 & 12.7 & 139 & 14.5 & \\
\hline 109.05 & 7.4 & 76.3 & 35.6 & 542 & 0.1 & & 7890 & 823 & 53.4 & 5.48 & 9.7 & 162 & 15.1 & 7.4 \\
\hline 133.13 & 7.2 & 71.6 & 35.6 & 540 & 0 & 189 & 7340 & 974 & 49.4 & 5.05 & 9.8 & 174 & 13.4 & \\
\hline 140.08 & 7.2 & 71.6 & 35.5 & 538 & 0 & 153 & 7660 & 914 & 47.6 & 4.91 & 9.7 & 162 & 16.2 & 4.9 \\
\hline 169.65 & 7.1 & 60.6 & 35.0 & 540 & 0.3 & 118 & 9900 & 1009 & 45.2 & 5.92 & 7.6 & 124 & 14.5 & 3.9 \\
\hline 198.76 & 7.4 & 67.2 & 35.0 & 544 & 0.1 & 118 & 10850 & 1061 & 42.0 & 6.77 & 6.2 & 193 & 16.5 & 5.6 \\
\hline 222.90 & 7.3 & 61.9 & 34.8 & 543 & 0.5 & 85 & 11580 & 1143 & 38.8 & 7.08 & 5.5 & 189 & 15.9 & 6.4 \\
\hline 252.59 & 7.5 & 52.1 & 33.5 & 546 & 0.1 & 47 & 12170 & 1050 & 36.6 & 7.22 & 5.1 & 155 & 16.2 & 8.1 \\
\hline 279.94 & 7.1 & 52.9 & 33.5 & 544 & 0.3 & 73 & 12130 & 1152 & 32.3 & 7.92 & 4.1 & 208 & 17.0 & 6.0 \\
\hline 309.65 & 7.1 & 46.3 & 33.0 & 541 & 0.4 & 47 & 11670 & 1206 & 28.0 & 7.96 & 3.5 & 201 & 15.5 & 3.2 \\
\hline 336.75 & 7.0 & 38.7 & 32.5 & 535 & 0.3 & 24 & 10190 & 1223 & 23.2 & 9.32 & 2.5 & 212 & 14.6 & 4.2 \\
\hline 369.50 & 7.3 & 38.8 & 32.0 & 533 & 0 & 42 & 9780 & 1335 & 18.6 & 9.96 & 1.9 & 212 & 16.5 & 4.2 \\
\hline 396.85 & 7.1 & 31.2 & 31.5 & 533 & 0.1 & 30 & 9510 & 1007 & 16.7 & 12.22 & 1.4 & 235 & 14.0 & 6.4 \\
\hline 424.75 & 6.9 & 22.3 & 31.5 & 527 & 2.0 & 5 & 8430 & 1262 & 15.5 & 11.02 & 1.4 & 159 & 13.2 & 8.1 \\
\hline 457.86 & 7.3 & 17.5 & 30.7 & 517 & 0.2 & 8 & 7080 & 812 & 12.3 & 12.87 & 1.0 & 208 & 13.4 & 3.5 \\
\hline 483.80 & 7.0 & 18.7 & 30.9 & 520 & 0.1 & 5 & 5830 & 823 & 13.7 & 13.02 & 1.1 & 220 & 10.5 & 5.3 \\
\hline 516.90 & 7.2 & 14.9 & 30.5 & 516 & 0 & 8 & 5160 & 761 & 14.9 & 13.47 & 1.1 & 212 & 8.4 & 5.3 \\
\hline \multicolumn{15}{|c|}{ Hole $798 \mathrm{C}$} \\
\hline 4.45 & 7.7 & 20.9 & 34.5 & 546 & & & 590 & 718 & 50.0 & 8.36 & 6.0 & 121 & 12.0 & 10.0 \\
\hline 21.25 & 7.6 & 53.9 & 34.0 & 532 & & 209 & 5020 & 919 & 52.4 & 5.08 & 10.3 & 130 & 14.0 & 4.0 \\
\hline
\end{tabular}

Trough may have been flanked by a subaerial landmass and may have accumulated fresh or brackish water. Another possible scenario that would allow accumulation of brackish water below the low-permeability sediments would be the migration of meteoric water from nearby subaerial regions through the porous sand units observed in the Site 799 sediments. Though evidence other than the presence of low-chloride interstitial waters in the lower sediments is not available, Oki Ridge (Site 798) may have experienced isolation from the open ocean and accumulated brackish water.

On the basis of biostratigraphy, benthic foraminifer stable isotopic signatures, and sedimentological evidence from piston cores collected at several shallow sites in the southern Japan Sea, Oba (1990) described paleoenvironmental changes in the Japan Sea over the last $85,000 \mathrm{yr}$, which include freshening events. He suggested that these freshening events may be related to Quaternary glacial/interglacial cycles that involve changes in meteoric water runoff from the Asian continent, coupled with eustatic changes and the temporary isolation of the Japan Sea from the open Pacific. During the Miocene, localized tectonic rather than global eustatic changes may have had similar results.

Miocene sediments were recovered from the lower sections of Site 799, but only Pliocene-Pleistocene sediments were penetrated at Site 798. If a Miocene source for brackish water is preserved below the depth of penetration at Site 798, slow diffusive exchange across the low-permeability units penetrated in the lower sections of Site 798 would allow the concentration gradients observed to be maintained.

Another mechanism that might explain low-chloride interstitial fluids is diagenetic reactions that involve the release of structural bound water from clay minerals and/or opal-A. Opal-A can be between 7 and 12 wt\% water (Knauth, 1973; Keene, 1976). Clay mineral water contents are extremely variable and can be as high as $10 \mathrm{wt} \%$ water (Brindley and Brown, 1980). Release of water by opal-A/opal-CT transformation and/or clay mineral recrystallization can significantly dilute formation fluid. On the basis of loss-on-ignition (LOI) analyses of bulk solids (little observable downcore changes in clay water content and mineralogy and little or no change in bulk sediment and clay-size fraction $\mathrm{K} / \mathrm{Al}$ molar ratio with depth; Tables 4,5 , and 6), there is no convincing evidence of significant clay mineral dehydration in these sediments.

The following exercise is a mass-balance calculation that predicts the possible dilution effect of opal-A-derived chloride-free water on interstitial water containing $540 \mathrm{mM}$ chloride if $1 \mathrm{~cm}^{3}$ of typical Site 799 opal-A-bearing sediment would expel all opal-A structural water. Sediments from the opal-A-bearing units at Site 799 contain about $20 \%$ opal-A (based on experiments by Burckle et al., this volume). In the upper portions of Hole 799A, sediment porosity is about $70 \%$. Below the opal-A/opal-CT transition, porosities decrease to below $50 \%$ and as low as $12 \%$ (Ingle, Suyehiro, von Breymann, et al., 1990). 
Table 2. Chemical composition of interstitial waters, Site 799, Kita-Yamato Trough.

\begin{tabular}{cccccccccccccccc}
\hline $\begin{array}{c}\text { Depth } \\
(\mathrm{mbsf})\end{array}$ & $\mathrm{pH}$ & $\begin{array}{c}\text { Alkalinity } \\
(\mathrm{mM})\end{array}$ & $\begin{array}{c}\text { Salinity } \\
(\mathrm{g} / \mathrm{kg})\end{array}$ & $\underset{(\mathrm{mM})}{\mathrm{Cl}}$ & $\begin{array}{c}\mathrm{SO}_{4} \\
(\mathrm{mM})\end{array}$ & $\begin{array}{c}\mathrm{PO}_{4} \\
(\mu \mathrm{M})\end{array}$ & $\underset{(\mathrm{M})}{\mathrm{NH}_{4}}$ & $\underset{(\mu \mathrm{M})}{\mathrm{SiO}_{2}}$ & $\underset{(\mathrm{mM})}{\mathrm{Mg}}$ & $\begin{array}{c}\mathrm{Ca} \\
(\mathrm{mM})\end{array}$ & $\mathrm{Mg} / \mathrm{Ca}$ & $\underset{(\mathrm{mM})}{\mathrm{Sr}}$ & $\begin{array}{c}\mathrm{K} \\
(\mathrm{mM})\end{array}$ & $\begin{array}{c}\mathrm{Li} \\
(\mu \mathrm{M})\end{array}$ & $\begin{array}{c}\mathrm{Mn} \\
(\mu \mathrm{M})\end{array}$ \\
\hline
\end{tabular}

Hole 799A

\begin{tabular}{|c|c|c|c|c|c|c|c|c|c|c|c|c|c|c|}
\hline 2.65 & 8.0 & 11.8 & 34.0 & 539 & 19.6 & 75.8 & 362 & 537 & 48.9 & 9.1 & 5.4 & 111 & 11.0 & 42 \\
\hline 16.50 & 7.8 & 32.5 & 33.5 & 534 & 2.9 & 196.3 & 1665 & 734 & 44.4 & 6.3 & 7.0 & 118 & 13.4 & 32 \\
\hline 16.55 & 7.7 & 33.2 & 33.5 & 531 & 2.9 & 161.2 & 1565 & 743 & 44.8 & 6.4 & 7.0 & & 12.9 & 32 \\
\hline 27.75 & 7.7 & 37.7 & 32.5 & 535 & 0.1 & 197.9 & 2038 & 1055 & 43.9 & 5.6 & 7.8 & 125 & 13.1 & 27 \\
\hline 35.85 & 7.6 & 38.1 & 32.0 & 531 & 0 & 193.1 & 2467 & 1007 & 44.0 & 4.9 & 9.1 & 135 & 12.2 & 35 \\
\hline 43.90 & 7.4 & 37.9 & 33.0 & 532 & 0 & 134.0 & 2396 & 775 & 44.3 & 4.3 & 10.4 & 138 & 11.5 & 39 \\
\hline 43.95 & 7.4 & 38.8 & 32.5 & 530 & 0.1 & 127.7 & 2439 & 771 & 44.9 & 4.4 & 10.3 & 145 & 11.2 & 44 \\
\hline 53.55 & 7.6 & 40.3 & 33.5 & 539 & 0 & 169.1 & 2610 & 911 & 43.4 & 4.3 & 10.1 & 147 & 12.2 & 49 \\
\hline 63.15 & 7.7 & 39.9 & 33.5 & 537 & 0.3 & 167.6 & 3026 & 928 & 44.3 & 4.2 & 10.6 & 154 & 11.6 & 39 \\
\hline 72.70 & 7.7 & 41.2 & 33.5 & 533 & 0 & 173.9 & 3126 & 930 & 43.9 & 4.1 & 10.8 & 159 & 10.8 & 53 \\
\hline 72.75 & 7.5 & 42.1 & 33.8 & 545 & 0 & 156.4 & 2811 & 921 & 45.3 & 4.2 & 10.7 & 162 & 10.8 & 52 \\
\hline 82.35 & 7.9 & 40.6 & 33.1 & 530 & 0 & 146.8 & 3426 & 1040 & 44.2 & 3.9 & 11.5 & 172 & 12.9 & 45 \\
\hline 103.10 & 7.7 & 38.9 & 33.3 & 536 & 0.1 & 109.8 & 3441 & 990 & 45.0 & 3.7 & 12.0 & 176 & 11.8 & 50 \\
\hline 103.15 & 7.6 & 40.4 & 33.2 & 530 & & 104.8 & 3412 & 1070 & 44.1 & 3.6 & 12.3 & 172 & 11.2 & 63 \\
\hline 132.00 & 7.9 & 36.8 & 32.7 & 531 & & 88.4 & 3942 & 836 & 41.7 & 3.6 & 11.6 & 174 & 12.3 & 43 \\
\hline 132.05 & 7.6 & 38.4 & 32.7 & 533 & 0 & 96.0 & 3884 & 896 & 43.8 & 3.7 & 11.9 & 193 & 12.0 & 50 \\
\hline 161.10 & & & & & & & & & & & & 213 & & \\
\hline 161.15 & 7.7 & 37.0 & 32.8 & 529 & & 83.4 & 3885 & 1132 & 43.9 & 3.4 & 13.0 & 213 & 9.6 & 54 \\
\hline 190.00 & 7.5 & 33.7 & 33.0 & 538 & & 71.4 & 4071 & 1123 & 42.8 & 3.1 & 14.0 & 215 & 9.7 & 45 \\
\hline 190.05 & 7.6 & 34.6 & 33.8 & 540 & 0.2 & 81.5 & 4058 & 1106 & 43.1 & 3.2 & 13.5 & 223 & 8.2 & 50 \\
\hline 220.50 & 7.7 & 30.1 & 32.5 & 535 & & 52.6 & 4400 & 1057 & 41.6 & 2.8 & 15.1 & 232 & 9.7 & 56 \\
\hline 220.55 & 7.7 & 31.3 & 33.5 & 536 & 0.2 & 48.8 & 3942 & 1080 & 41.6 & 3.0 & 14.0 & 232 & 11.1 & 60 \\
\hline 244.30 & 7.5 & 28.3 & 32.5 & 541 & & 48.8 & 4357 & 1199 & 39.8 & 3.3 & 12.0 & 240 & 7.9 & 56 \\
\hline 244.35 & 7.6 & 31.1 & 33.0 & 540 & 0.1 & 65.8 & 4185 & 1209 & 40.6 & 3.2 & 12.6 & 249 & 8.4 & 55 \\
\hline 267.90 & 7.7 & 25.9 & 32.4 & 536 & & 34.3 & 4472 & 1222 & 37.8 & 3.4 & 11.1 & 230 & 8.3 & 58 \\
\hline 267.95 & 7.6 & 26.8 & 32.5 & 536 & 0.4 & 40.6 & 4758 & 1272 & 38.6 & 3.5 & 11.0 & 245 & 9.6 & 48 \\
\hline 295.30 & 6.5 & 25.7 & 32.3 & 534 & & 29.9 & 4844 & 1242 & 36.1 & 3.2 & 11.2 & 254 & 7.3 & 64 \\
\hline 295.35 & 7.2 & 26.1 & 32.5 & 535 & 0.2 & 35.0 & 4758 & 1257 & 36.0 & 3.6 & 10.1 & 261 & 7.0 & 71 \\
\hline 321.30 & 6.1 & 22.8 & & 533 & & 35.0 & 5216 & 1478 & 33.2 & 4.1 & 8.1 & 242 & 7.7 & 80 \\
\hline 321.35 & 6.7 & 25.0 & 32.3 & 534 & 0.3 & 41.9 & 5059 & 1506 & 34.2 & 4.0 & 8.5 & 271 & 7.9 & 66 \\
\hline 350.30 & 5.8 & 21.7 & 32.0 & 529 & & 10.4 & 5302 & 1467 & 31.9 & 4.3 & 7.4 & 242 & 7.6 & 77 \\
\hline 350.35 & 6.4 & 23.6 & 32.1 & 532 & 0.2 & 19.2 & 5130 & 1484 & 32.5 & 4.5 & 7.2 & 262 & 6.8 & 96 \\
\hline 380.90 & 5.0 & 20.6 & 31.6 & 530 & & 4.2 & 5746 & 1570 & 29.5 & 4.5 & 6.6 & 242 & 6.9 & 82 \\
\hline 380.95 & 6.0 & 21.4 & 31.7 & 529 & 0.4 & 8.6 & 5288 & 1596 & 30.6 & 4.5 & 6.8 & 249 & 7.0 & 98 \\
\hline 408.30 & 5.0 & 19.3 & 31.6 & 525 & & 2.9 & 5374 & 1506 & 26.6 & 4.8 & 5.5 & 281 & 6.0 & 111 \\
\hline 408.35 & 5.7 & 21.7 & 31.7 & 522 & 0.3 & 3.5 & 5202 & 1527 & 27.7 & 5.0 & 5.5 & 259 & 6.0 & 103 \\
\hline 435.80 & 5.3 & 18.5 & 31.6 & 524 & 0.2 & 0.4 & 5674 & 1480 & 24.5 & 4.9 & 5.0 & 257 & 5.1 & 141 \\
\hline 464.80 & & & 29.8 & & & & 4715 & 857 & 22.8 & 5.4 & 4.2 & 266 & 3.7 & 177 \\
\hline 464.85 & 6.5 & 20.0 & & 506 & 0 & 1.6 & & & & & & 274 & & \\
\hline
\end{tabular}

Hole 799B

\begin{tabular}{|c|c|c|c|c|c|c|c|c|c|c|c|c|c|}
\hline 493.90 & 7.5 & 9.7 & 32.2 & 531 & 5429 & 779 & 22.1 & 6.6 & 3.4 & 158 & 4.6 & 196 & 22 \\
\hline 497.50 & 7.1 & & 31.0 & 525 & 4203 & 802 & 22.4 & 8.1 & 2.8 & 211 & 4.5 & 227 & 34 \\
\hline 502.60 & 7.2 & 11.5 & 30.4 & 528 & 5045 & 791 & 20.7 & 7.5 & 2.8 & 193 & 5.1 & 207 & 29 \\
\hline 531.50 & 7.4 & 11.3 & 30.0 & 525 & 5045 & 733 & 18.6 & 8.8 & 2.1 & 163 & 4.6 & 227 & 30 \\
\hline 552.30 & 7.4 & & 28.2 & 501 & 3641 & 690 & 20.4 & 9.1 & 2.2 & 225 & 3.2 & 234 & 42 \\
\hline 582.90 & 7.5 & 8.2 & 29.5 & 508 & 4306 & 600 & 17.9 & 8.7 & 2.1 & 257 & 2.9 & 195 & 39 \\
\hline 591.00 & 7.3 & 6.8 & 29.5 & 514 & 4927 & 378 & 16.6 & 9.4 & 1.8 & 254 & 3.2 & 149 & 32 \\
\hline 600.70 & 7.6 & 7.1 & 29.8 & 512 & 4794 & 265 & 16.9 & 8.5 & 2.0 & 247 & 3.1 & 166 & 63 \\
\hline
\end{tabular}

We have chosen to use $70 \%$ porosity for the following calculation because that would be representative of the original sediment/fluid ratio before diagenetic transformation. Measured grain densities for these sediments are about $2.5 \mathrm{~g} / \mathrm{cm}^{3}$ (Ingle, Suyehiro, von Breymann, et al., 1990) and the density of seawater is $1.023 \mathrm{~g} / \mathrm{cm}^{3}$. From this, and relative masses of sediments and water in $1 \mathrm{~cm}^{3}$ of sediment, we can calculate as follows:

$$
\begin{gathered}
\left(1.023 \mathrm{~g} / \mathrm{cm}^{3}\right) \cdot\left(0.7 \mathrm{~cm}^{3}\right)=0.716 \mathrm{~g} \text { fluid } \\
\left(2.5 \mathrm{~g} / \mathrm{cm}^{3}\right) \cdot\left(1 \mathrm{~cm}^{3}-0.7 \mathrm{~cm}^{3}\right)=0.750 \mathrm{~g} \text { solid. }
\end{gathered}
$$

Of the $0.750 \mathrm{~g}$ sediment in $1 \mathrm{~cm}^{3}, 20 \%$ is opal-A, containing up to 12 wt $\%$ water (Keene, 1976). Thus, $(0.750 \mathrm{~g}$ solid $) \cdot(20 \%) \cdot(12 \%)=$ $0.018 \mathrm{~g}$ chloride-free fluid that can be added to the interstitial fluids from $1 \mathrm{~cm}^{3}$ sediment. The percentage increase of chloride-free fluid can be calculated as follows:

$$
100(0.0180 \mathrm{~g}) /(0.716 \mathrm{~g}+0.018 \mathrm{~g})=2.5 \%
$$

From the latter calculation, one could expect no more than $2.5 \%$ dilution of interstitial water chloride concentration from opal-A-released chloride-free fluid. Interstitial water chloride concentration in the upper $200 \mathrm{~m}$ at Site 799 is near the Japan Sea seawater value, $540 \mathrm{mM}$. Below the opal-A/opal-CT boundary, interstitial water drops to as low as $501 \mathrm{mM}$ chloride. The change in chloride concentration is greater than $7 \%$, more than twice what one would expect from opal-A water release. If one does a similar calculation using a porosity of $50 \%$, as is observed at Site 799 below the opal-A/opal-CT transition, the dilution from interstitial water chloride concentration from opal-Areleased chloride-free fluid would be $5.5 \%$, still lower than one would expect from opal-A water release.

One could do a similar calculation for water that might be released from clay mineral dehydration. Assuming a maximum water loss of $10 \%$ (Brindley and Brown, 1980) and assuming 20\% of the starting sediment is clay minerals (based on the quantitative settling of Core 128-799A-1H, $16.5 \mathrm{mbsf}$ ), and $70 \%$ initial porosity, the percentage mass of fluid released to mass final volume is $2.05 \%$. Even if one invokes the sum of opal-A plus clay-mineral released 

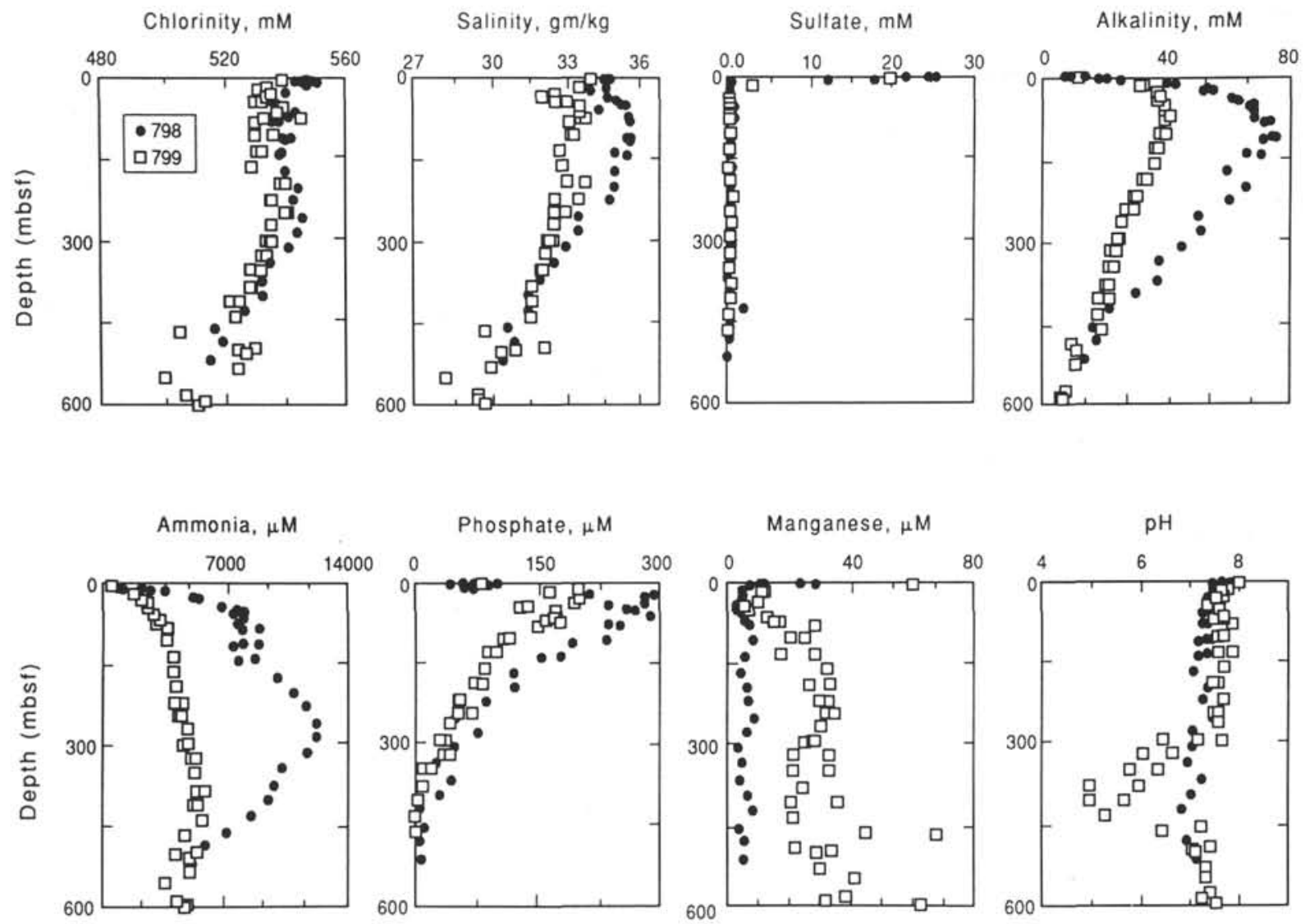

Figure 2. Interstitial water composition vs. depth.

water, the total is near 5\%, still less than the observed chloride dilution in the interstitial waters below the low-permeability units at Site 799. As noted above, there is no convincing evidence of significant clay mineral dehydration in these sediments.

Another avenue through which one might distinguish between dilution contributions from opal-A and/or clay mineral diagenesis and connate brackish water is oxygen and hydrogen isotopic ratios. One would expect mixtures of local freshwater and seawater to fall on the meteoric water line of Craig (1961) (Henley et al., 1984) (Fig. 4). Interstitial waters from Site 799 show a general trend toward lighter $\delta \mathrm{D}$ and $\delta^{18} \mathrm{O}$ with depth (Table 3 ) and much lighter values at and below 400 mbsf. This suggests that they might have been influenced by some component of freshwater and seawater mixing. However, if the marine interstitial waters were affected only by dilution with meteoric waters (i.e., if the chloride signature in the lower parts of the hole is that of connate brackish water) then the isotopic signatures should plot closer than they do to the meteoric water line (Fig. 4). That is, all but one sample analyzed exhibit relatively heavy $\delta \mathrm{D}$ for the measured $\delta^{18} \mathrm{O}$ or relatively light $\delta^{18} \mathrm{O}$ for measured $\delta \mathrm{D}$. Some process other than simple mixing between local fresh water and seawater must be influencing the interstitial water isotopic signatures.

Oxygen isotope values in cherts range between +10 and +40 (Kolodny and Epstein, 1976; Field and Fifarek, 1985). Fluids expelled from opal-A by the opal-A/opal-CT transformation have lighter oxygen isotope values than the cherts themselves, but are still heavier than SMOW (Matheney and Knauth, 1989). The data presented in Table 3 indicate that the oxygen isotope values measured for the Site 799 interstitial waters have relatively light $\delta^{18} \mathrm{O}$, lighter than SMOW. Thus, these data cannot be explained by invoking opal-A/opal-CT diagenesis, nor entirely by freshwater/seawater mixing.

\section{Sediments}

Interstitial water chloride distributions suggest that shallow ridges in the Japan Sea may have experienced an episode of low-salinity conditions, perhaps as brackish water lakes, during the Miocene. In order to further investigate the possibility of Miocene age brackish water lake sediment accumulation, we measured the major element molar ratios and minor and trace elements in the bulk and clay-sizefraction sediment and in carbonate nodules.

\section{Bulk Sediments}

According to shipboard observations and analyses, surface sediments at both Sites 798 and 799 are dominated by biogenic components, such as biogenic carbonate and biogenic silica (Ingle, Suyehiro, von Breymann, et al., 1990). Ash layers are abundant in the upper $400 \mathrm{~m}$ and become less abundant with depth (Ingle, Suyehiro, von Breymann, et al., 1990; also see Pouclet et al., this volume). Dolomite occurs as hard dolomite-cemented layers below 383 mbsf at Site 798 and as concretions and dolomite-cemented layers below 200 mbsf at Site 799 (Ingle, Suyehiro, von Breymann, et al., 1990). Shipboard X-ray diffraction analyses document the presence of opal-CT below $450 \mathrm{mbsf}$ at Site 798 and below $410 \mathrm{mbsf}$ at Site 799. Clay mineral crystallization is suggested by the removal of potassium and decreasing alkalinity and $\mathrm{pH}$ below $300 \mathrm{mbsf}$ at both sites. According to X-ray diffraction analyses, large changes in clay mineralogy, clay mineral abundance, and degree of crystallinity are not observed at either site. The occurrence of opal-CT and dolomite in the sediments coincides with high-bulk-density and low-porosity layers (Ingle, Suyehiro, von Breymann, et al., 1990). 

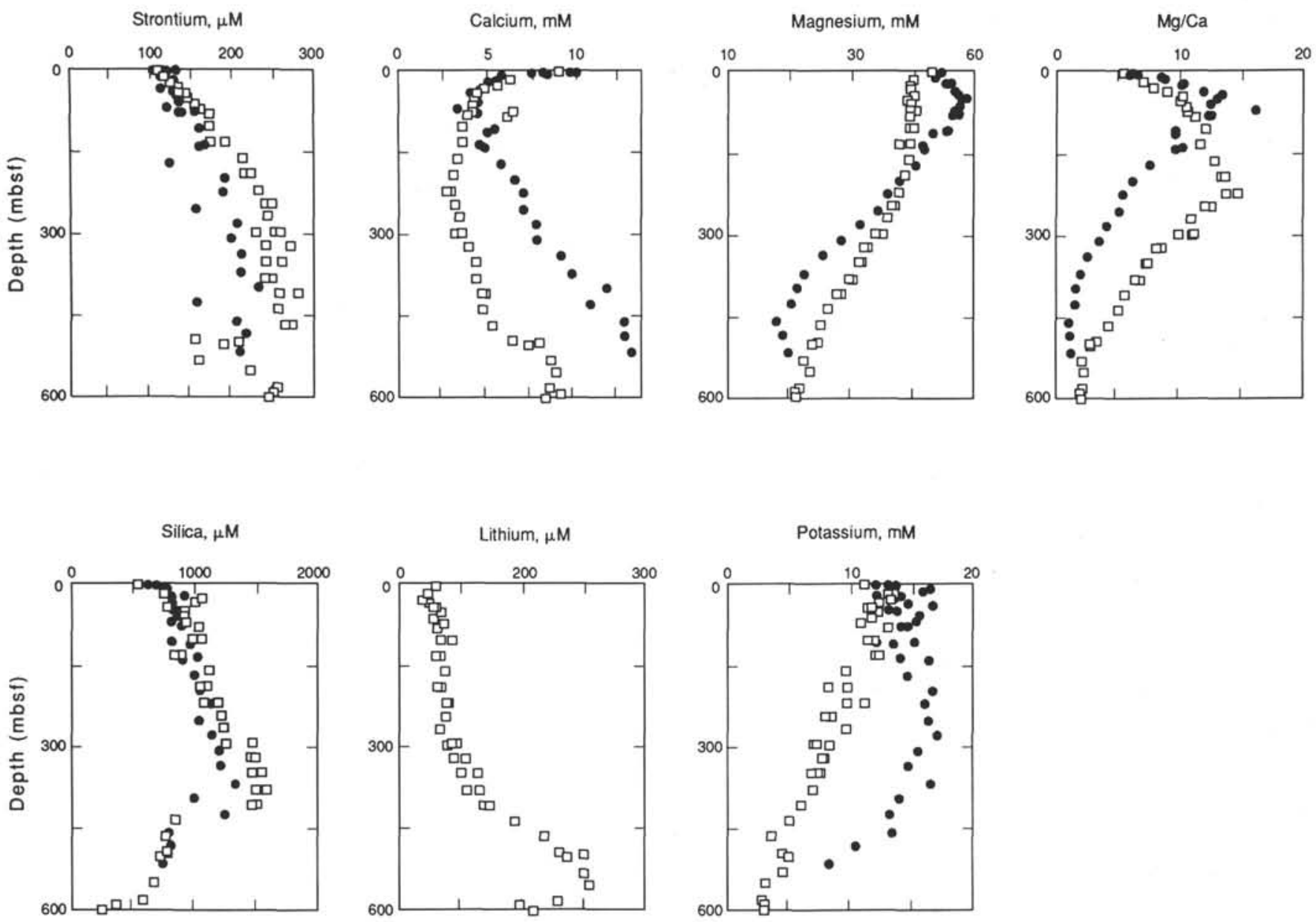

Figure 2 (continued).

Major element molar ratios do not exhibit downcore variation that can be attributed to exposure to brackish water. Profiles of major element molar ratios are nearly constant, with little or no downcore variation (Figs. 5 and 6). $\mathrm{Na} / \mathrm{Al}$ vs. depth shows a slight decrease with depth, but does not show a sharp decrease in the lower portions of the hole. Similarly, bulk-sediment trace element variations do not indicate a change in diagenetic environment salinity.

\section{Clay-size Fraction}

At relatively low temperatures of alteration where diagenetic reactions proceed, the geochemical overprint produced by brackish vs. marine diagenetic alteration is expected to be small. The bulk-sediment chemical composition would be dominated by the original pelagic sediment assemblage. The chemistry and mineralogy of authigenic precipitates would be more indicative of the geochemical system. Authigenic precipitates are expected to be small, $<2 \mu \mathrm{m}$, and clay minerals are commonly observed secondary minerals.

Clay-size-fraction separates for six intervals from Site 799 were analyzed. The results of chemical analyses of these separates are given in Table 5. According to X-ray diffraction analyses, the clay-size fractions of all six intervals contain kaolinite, illite, quartz, and carbonates. Carbonates contained in the clay-size fraction from the upper portions of the hole are calcite. Carbonates contained in the clay-size fraction of the lower portions of the hole are proto-dolomite and siderite. On the basis of relative peak height, the carbonates make up only a very small portion of the clay-size fraction. Major element molar ratios of the clay-size fractions do not show significant downcore variations (Fig. 7). Metals such as $\mathrm{Ti}, \mathrm{Fe}, \mathrm{Cu}$, and $\mathrm{Zn}$ decrease with depth (Fig. 7). However, none of these elements shows marked changes across the low-permeability, high-bulk-density boundary. Thus, the clay-size-fraction geochemical signatures do not support the suggestion from the interstitial water chloride variations that the Miocene-age sediments at Site 799 have experienced a low-salinity event. However, it should be noted that interstitial water chemical signatures are much more sensitive to diagenetic and/or dilution changes than solid geochemical signatures.

\section{Carbonates}

According to X-ray diffraction analyses, carbonate nodules recovered from bulk sediments from Cores 128-799A-51X, 128-799B-6R, 128799B-10R, 128-799B-12R, 128-799B-15R, 128-799B-17R, 128-799B$18 \mathrm{R}$, and 128-799B-21R, all below the opal-A/CT-boundary, are an intimate mixture of dolomite or protodolomite (2.91 $\AA d$-spacing) and siderite ( $2.76 \AA d$-spacing) (also see Matsumoto, this volume). The siderite and protodolomite X-ray diffraction peaks are well defined but broad and not very sharp, suggesting that the carbonates are not well crystallized. Molar concentrations and oxide percentages of calcium, magnesium, iron, and manganese from three dissolved nodules are given 
Table 3. Interstitial-water stable isotope ratios, Site 799.

\begin{tabular}{|c|c|c|c|c|c|c|}
\hline Core, section & $\begin{array}{l}\text { Depth } \\
\text { (mbsf) }\end{array}$ & ${ }^{87} \mathrm{Sr} /{ }^{86} \mathrm{Sr}$ & $\begin{array}{c}\mathrm{Sr} \\
(\mu \mathrm{M})\end{array}$ & $\delta^{13} \mathrm{C}$ & $8^{18} \mathrm{O}$ & $\delta \mathrm{D}$ \\
\hline \multicolumn{7}{|l|}{ 128-799A- } \\
\hline $3 \mathrm{H}-4$ & 16.5 & 0.70883 & 118 & $-23.84,-23.88$ & -0.3 & $-3,-4$ \\
\hline $24 X-5$ & 220.5 & 0.70897 & 232 & -5.34 & -1.5 & $-1,-3$ \\
\hline $45 X-3$ & 408.3 & 0.70873 & 281 & -8.11 & -3.8 & $-16,-13$ \\
\hline $51 X-2$ & 464.8 & 0.70870 & 274 & $-11,47$ & -3.9 & $-14,-12$ \\
\hline \multicolumn{7}{|l|}{$128-799 \mathrm{~B}-$} \\
\hline $7 \mathrm{R}-2$ & 502.6 & 0.70761 & 193 & & & \\
\hline $10 \mathrm{R}-2$ & 531.5 & & & & -4.1 & $-8,-10$ \\
\hline $16 \mathrm{R}-3$ & 591.0 & 0.70864 & 254 & & & \\
\hline $17 \mathrm{R}$ & 600.7 & & & -10.29 & -4.3 & $-12,-14$ \\
\hline
\end{tabular}

Note: Two values are given where duplicate analyses were run.

in Table 7. The presence of iron- and manganese-bearing carbonates has been described by Berner (1981) as indicative of anoxic-nonsulfidic sediments. Such diagenetic conditions occur when interstitial water sulfate has become depleted and thus prevents diagenetic sulfides from forming even though dissolved iron and manganese remain available. Under these conditions methanogenesis proceeds and dissolved iron and manganese can build up in interstitial waters.

Anoxic-nonsulfidic sediments have been described in both marine and lacustrine environments (Emerson and Widmer, 1978; Martens and Berner, 1977; Martens et al., 1978; Froelich et al., 1979). However, brackish water contains lower concentrations of dissolved sulfate. With same relative rates of bacterially mediated organic matter degradation and sulfate reduction, sulfate will be depleted more rapidly in brackish interstitial waters than in marine interstitial waters. The necessary environmental conditions for dolomite and siderite formation would occur more quickly under brackish water conditions than marine conditions. The presence of dolomite and siderite is certainly not conclusive evidence for Miocene-age brackish water. In fact, siderite has been observed in marine sediments, for instance at Deep Sea Drilling Project (DSDP) Site 148 (J. Gieskes, pers. comm., 1990). The presence of siderite does show, however, that diagenesis of the Miocene sediments proceeded under conditions of very rapid sulfate depletion with excess dissolved iron and manganese in the interstitial waters.

\section{CONCLUSIONS}

Sites 798 and 799 can be described in terms of the geochemical processes that dominate interstitial water chemical composition. The uppermost sediments are characterized by early diagenetic processes related to organic matter decomposition accompanied by sulfate reduction, alkalinity, phosphate, and ammonia release and biogenic carbonate recrystallization. Interstitial water chemical composition below 70 mbsf at Site 798 and below 220 mbsf at Site 799 reflects dolomitization and biogenic silica dissolution. Below $300 \mathrm{mbsf}$ at both sites the interstitial waters are chemically different from those in the overlying sediments. The change in interstitial water chemical composition coincides with lithologic layers of low permeability and high bulk density. The data presented in this study suggest that silica diagenesis has influenced the chemical composition of the interstitial water present below the low-permeability, high-bulk-density layers. However, silica diagenesis does not entirely account for the observed interstitial water chloride concentrations in the lowermost sediments. Miocene age connate brackish water may contribute to the observed interstitial water chemical composition.

\section{ACKNOWLEDGMENTS}

This work was supported by the Joint Oceanographic Institutions United States Science Support Program. Thanks to Wendy Dunlap and Andrea Perea, of the University of San Diego, for laboratory assistance and help with manuscript preparation. Thanks to Joris Gieskes, Dale Buckley, Margaret Delaney, and an anonymous reviewer for thoughtful, constructive criticism.

\section{REFERENCES}

Berner, R. A., 1981. A new geochemical classification of sedimentary environments. J. Sediment. Petrol., 51:359-365.

Brindley, G. W., and Brown, G., 1980. Crystal structures of clay minerals and their X ray identification. London Mineral. Soc. Monogr., 5.

Burckle, L. H., and Akiba, F., 1978. Implications of late Neogene fresh-water sediment in the Sea of Japan. Geology, 6:123-127.

Craig, H., 1961. Isotopic variations in meteoric waters. Science, 133:1702-1703.

DePaolo, D. J., 1986. Detailed record of the Neogene $\mathrm{Sr}$ isotope evolution of seawater from DSDP Site 590B. Geology, 14:103-106.

Emerson, S., and Widmer, G., 1978. Early diagenesis in anaerobic lake sediments. Thermodynamic and kinetic factors controlling the formation of iron phosphate. Geochim. Cosmochim. Acta, 42:1307-1316.

Field, C., and Fifarek, R. H., 1985. Light stable isotope systematics in the epithermal environment. In Berger, B. R., and Bethke, P. M. (Eds.), Geology and Geochemistry of Epithermal Systems: Reviews in Economic Geology (Vol. 2). Soc. Econ. Geol., 99-128.

Froelich, P., Klinkhammer, G., Bender, M., Luedtke, N., Heath, G., Cullen, D., Dauphin, P., Hammond, D., Hartman, B., and Maynard, V., 1979. Early oxidation of organic matter in pelagic sediments of eastern equatorial Atlantic: suboxic diagenesis. Geochim. Cosmochim. Acta, 43:1075-1090.

Gieskes, J. M., and Peretsman, G., 1986. Water chemistry procedures aboard JOIDES Resolution-some comments. ODP Tech. Note, 5.

Gnibidenko, H., 1979. The tectonics of the Sea of Japan. Mar. Geol., 32:71-87.

Henley, W. R., Trusdell, A. H., and Barton, P. B., Jr., 1984. Fluid-mineral equilibria in hydrothermal systems. Society of Economic Geologists: Reviews in Economic Geology (Vol. 1). Soc. Econ. Geol., 267.

Hess, J., Bender, M. L., and Schilling, J.-G., 1986. Seawater ${ }^{87} \mathrm{Sr} /{ }^{86} \mathrm{Sr}$ evolution from Cretaceous to Present-applications to paleoceanography. Science, 231:979-984.

Ingle, J. C., Jr., 1975. Pleistocene and Pliocene foraminifera from the Japan Sea Leg 31, Deep Sea Drilling Project. In Karig, D. E., Ingle, J. C., Jr., et al., Init. Repts. DSDP, 31: Washington (U. S. Govt. Printing Office), 693-701.

, 1990. Paleoceanography of the Japan Sea-a synthesis of Legs 127/128 results [paper presented at ODP Japan Sea Symp., Tokyo, October, 1990].

Ingle, J. C., Jr., Suyehiro, K., von Breymann, M. T., et al., 1990. Proc. ODP, Init. Repts., 128: College Station, TX (Ocean Drilling Program).

Ingle, J. C., Jr., Suyehiro, K., von Breymann, M. T., and the Leg 128 Shipboard Scientific Party, 1990. ODP in the Japan Sea. Geotimes, 9267:25-27.

Ingram, B. L., and DePaolo, D. J., 1985. High-resolution stratigraphy with strontium isotopes. Science, 227:939-941.

Kaneoka, I., 1990. ${ }^{40} \mathrm{Ar}^{39} \mathrm{Ar}$ dating of volcanic rocks recovered by Leg 127 drilling [paper presented at ODP Japan Sea Symp., Tokyo, October, 1990].

Keene, J. B., 1976. The distribution, mineralogy, and petrography of biogenic and authigenic silica from the Pacific Basin [Ph.D. dissert.]. Scripps Inst. Oceanogr., 264.

Knauth, L. P., 1973. Oxygen and hydrogen isotope ratios in cherts and related rocks [Ph.D dissert.]. California Inst. Technol.

Kolodny, Y., and Epstein, S., 1976. Stable isotope geochemistry of seed sea cherts. Geochim. Cosmochim. Acta, 40:1195-1209.

Ludwig, W. J., Murauchi, S., and Houtz, R. E., 1975. Sediments and structure of the Japan Sea. Geol. Soc. Am. Bull., 86:651-664.

Martens, C. S., and Berner, R. A., 1977. Interstitial water chemistry of anoxic Long Island Sound sediments. 1. Dissolved gases. Limnol. Oceanogr., 22:10-25.

Martens, C. S., Berner, R. A., and Rosenfeld, J. K., 1978. Interstitial water chemistry of anoxic Long Island Sound sediments. 2. Nutrient regeneration and phosphate removal. Limnol. Oceanogr., 23:605-617. 
Matheney, R. K., and Knauth, L. P., 1989. Oxygen-isotope fractionation between marine biogenic silica and seawater. Geochim. Cosmochim. Acta, 53:3207-3214.

Matoba, Y., 1984. Paleoenvironment of the Sea of Japan: Benthos '83, 2nd Inter. Symp. Benthic Foraminifers (Pau, April 1983), 409-415.

McKenzie, J. A., Hodell, D. A., Mueller, P. A., and Mueller, D. W., 1988. Application of strontium isotopes to late Miocene-early Pliocene stratigraphy. Geology, 16:1022-1025.

Oba, T., 1990. Paleoenvironmental change of the Japan Sea in the last 85,000 years [paper presented at ODP Japan Sea Symp., Tokyo, October, 1990].
Tamaki, K., 1988. Geological structure of the Japan Sea and its tectonic implications. Chishitsu Chosasho Geppo, 39:269-365.

Tamaki, K., Pisciotto, K., Allan, J., et al., 1990. Proc. ODP, Init. Repts., 127: College Station, TX (Ocean Drilling Program).

Date of initial receipt: 18 March 1991

Date of acceptance: 15 November 1991

Ms 127/128B-161

Table 4. Chemical composition (salt corrected) of bulk sediments, Site 799.

\begin{tabular}{|c|c|c|c|c|c|c|c|c|c|c|c|c|}
\hline Core & $\begin{array}{l}\text { Depth } \\
\text { (mbsf) }\end{array}$ & $\mathrm{Si} / \mathrm{Al}$ & $\mathrm{Ca} / \mathrm{Al}$ & $\mathrm{Mg} / \mathrm{Al}$ & $\mathrm{Mg} / \mathrm{Ca}$ & $\mathrm{K} / \mathrm{Al}$ & $\mathrm{Na} / \mathrm{Al}$ & $\mathrm{Ti} / \mathrm{Al}$ & $\mathrm{Fe} / \mathrm{Al}$ & $\begin{array}{c}\mathrm{Zn} \\
(\mathrm{mg} / \mathrm{kg})\end{array}$ & $\begin{array}{c}\mathrm{Cu} \\
(\mathrm{mg} / \mathrm{kg})\end{array}$ & $\begin{array}{l}\text { LOI } \\
(\%)\end{array}$ \\
\hline \multicolumn{13}{|c|}{$128-799 \mathrm{~A}-$} \\
\hline $1 \mathrm{H}$ & 0.5 & 2.87 & 0.056 & 0.253 & 4.50 & 0.261 & 0.709 & 0.0263 & 0.216 & 94.6 & 43 & 14.6 \\
\hline $2 \mathrm{H}$ & 2.7 & 2.89 & 0.136 & 0.228 & 1.68 & 0.246 & 0.613 & 0.0287 & 0.247 & 200.4 & 92 & 10.4 \\
\hline $3 \mathrm{H}$ & 16.5 & 2.97 & 0.126 & 0.233 & 1.85 & 0.291 & 0.656 & 0.0248 & 0.221 & 205.6 & 98 & 15.1 \\
\hline $4 \mathrm{H}$ & 27.8 & 3.31 & 0.202 & 0.261 & 1.29 & 0.254 & 0.686 & 0.0307 & 0.259 & 55.8 & 24 & 15.7 \\
\hline $5 \mathrm{H}$ & 35.9 & 3.36 & 0.144 & 0.293 & 2.04 & 0.314 & 0.584 & 0.0394 & 0.291 & 88.5 & 39 & 9.0 \\
\hline $6 \mathrm{H}$ & 43.9 & 3.50 & 0.278 & 0.303 & 1.09 & 0.272 & 0.671 & 0.0177 & 0.177 & 141.8 & 69 & 14.2 \\
\hline $7 \mathrm{H}$ & 53.5 & 3.06 & 0.159 & 0.252 & 1.58 & 0.265 & 0.590 & 0.0361 & 0.266 & 165.2 & 76 & 9.6 \\
\hline $8 \mathrm{H}$ & 63.2 & 3.81 & 0.302 & 0.255 & 0.84 & 0.263 & 0.648 & 0.0248 & 0.211 & 97.1 & 45 & \\
\hline $9 \mathrm{H}$ & 72.7 & 3.35 & 0.265 & 0.197 & 0.74 & 0.203 & 0.544 & 0.0216 & 0.198 & 77.3 & 33 & \\
\hline $10 \mathrm{H}$ & 82.4 & 2.80 & 0.241 & 0.198 & 0.82 & 0.193 & 0.521 & 0.0249 & 0.204 & 79.2 & 36 & 11.7 \\
\hline $11 \mathrm{H}$ & 92.0 & 3.20 & 0.134 & 0.242 & 1.80 & 0.256 & 0.608 & 0.0238 & 0.284 & 159.8 & 73 & 12.3 \\
\hline $12 \mathrm{H}$ & 103 & 3.03 & 0.118 & 0.302 & 2.57 & 0.311 & 0.573 & 0.0278 & 0.292 & 147.1 & 67 & 8.9 \\
\hline $13 \mathrm{H}$ & 113 & 3.00 & 0.101 & 0.299 & 2.96 & 0.280 & 0.505 & 0.0206 & 0.225 & 199.6 & 89 & 11.1 \\
\hline $14 \mathrm{H}$ & 122 & 2.69 & 0.079 & 0.220 & 2.80 & 0.230 & 0.488 & 0.0293 & 0.280 & 148.4 & 72 & 10.7 \\
\hline $16 \mathrm{H}$ & 141 & 2.72 & 0.090 & 0.269 & 2.98 & 0.240 & 0.441 & 0.0225 & 0.262 & 160.8 & 74 & 9.3 \\
\hline $17 \mathrm{H}$ & 151 & 3.11 & 0.116 & 0.341 & 2.93 & 0.224 & 0.574 & 0.0351 & 0.251 & 154.3 & 69 & 12.0 \\
\hline $18 \mathrm{H}$ & 161 & 2.95 & 0.094 & 0.323 & 3.45 & 0.218 & 0.507 & 0.0274 & 0.250 & 114.6 & 53 & 13.7 \\
\hline $20 \mathrm{H}$ & 180 & 2.91 & 0.094 & 0.301 & 3.19 & 0.206 & 0.551 & 0.0296 & 0.169 & 174.3 & 80 & 12.8 \\
\hline $22 \mathrm{X}$ & 200 & 2.97 & 0.082 & 0.250 & 3.06 & 0.187 & 0.497 & 0.0227 & 0.209 & 203.4 & 97 & 15.3 \\
\hline $29 \mathrm{X}$ & 256 & 3.27 & 0.112 & 0.252 & 2.24 & 0.218 & 0.545 & 0.0274 & 0.170 & 181.6 & 80 & 13.3 \\
\hline $35 \mathrm{X}$ & 313 & 3.29 & 0.091 & 0.272 & 2.99 & 0.194 & 0.587 & 0.0158 & 0.125 & 113.0 & 47 & 10.3 \\
\hline $39 \mathrm{X}$ & 350 & 3.30 & 0.131 & 0.232 & 1.77 & 0.204 & 0.566 & 0.0172 & 0.167 & 149.5 & 64 & 13.5 \\
\hline $45 \mathrm{X}$ & 408 & 3.09 & 0.116 & 0.349 & 3.01 & 0.232 & 0.527 & 0.0196 & 0.197 & 220.9 & 97 & 15.1 \\
\hline $50 \mathrm{X}$ & 464 & 3.08 & 0.119 & 0.304 & 2.55 & 0.211 & 0.466 & 0.0177 & 0.222 & 198.5 & 89 & 14.3 \\
\hline \multicolumn{13}{|l|}{$128-799 \mathrm{~B}-$} \\
\hline $7 \mathrm{R}$ & 503 & 3.47 & 0.108 & 0.204 & 1.89 & 0.166 & 0.420 & 0.0159 & 0.197 & 237.0 & 108 & \\
\hline $12 \mathrm{R}$ & 552 & 3.17 & 0.077 & 0.127 & 1.65 & 0.169 & 0.396 & 0.0171 & 0.229 & 231.0 & 105 & 14.6 \\
\hline $17 \mathrm{R}$ & 600 & 2.99 & 0.108 & 0.254 & 2,35 & 0.233 & 0.411 & 0.0160 & 0.203 & 220.5 & 99 & \\
\hline $23 \mathrm{R}$ & 656 & 2.97 & 0.100 & 0.282 & 2.82 & 0.221 & 0.393 & 0.0194 & 0.167 & 214.9 & 97 & 13.8 \\
\hline $26 \mathrm{R}$ & 685 & 3.27 & 0.109 & 0.254 & 2.32 & 0.248 & 0.405 & 0.0189 & 0.204 & 268.9 & 125 & 9.7 \\
\hline $28 \mathrm{R}$ & 706 & 3.32 & 0.116 & 0.291 & 2.50 & 0.234 & 0.383 & 0.0220 & 0.215 & 265.2 & 115 & 14.5 \\
\hline $49 \mathrm{R}$ & 905 & 3.01 & 0.052 & 0.326 & 6.33 & 0.242 & 0.409 & 0.0202 & 0.192 & 161.4 & 73 & 14.0 \\
\hline $54 \mathrm{R}$ & 955 & 3.01 & 0.037 & 0.313 & 8.43 & 0.230 & 0.438 & 0.0247 & 0.203 & 155.3 & 75 & 14.6 \\
\hline $62 \mathrm{R}$ & 1032 & 3.26 & 0.028 & 0.258 & 9.30 & 0.256 & 0.398 & 0.0264 & 0.142 & 181.7 & 66 & 8.9 \\
\hline
\end{tabular}

Note: $\mathrm{Si} / \mathrm{Al}, \mathrm{Ca} / \mathrm{Al}, \mathrm{Mg} / \mathrm{Al}, \mathrm{Mg} / \mathrm{Ca}, \mathrm{K} / \mathrm{Al}, \mathrm{Na} / \mathrm{Al}, \mathrm{Ti} / \mathrm{Al}$, and $\mathrm{Fe} / \mathrm{Al}$ are molar ratios.

Table 5. Chemical composition of the clay-size fraction.

\begin{tabular}{ccccccccccccc}
\hline Core & $\begin{array}{c}\text { Depth } \\
(\mathrm{mbsf})\end{array}$ & $\mathrm{Si} / \mathrm{Al}$ & $\mathrm{Ca} / \mathrm{Al}$ & $\mathrm{Mg} / \mathrm{Al}$ & $\mathrm{Mg} / \mathrm{Ca}$ & $\mathrm{K} / \mathrm{Al}$ & $\mathrm{Na} / \mathrm{Al}$ & $\mathrm{Ti} / \mathrm{Al}$ & $\mathrm{Fe} / \mathrm{Al}$ & $\begin{array}{c}\mathrm{Zn} \\
(\mathrm{mg} / \mathrm{kg})\end{array}$ & $\begin{array}{c}\mathrm{Cu} \\
(\mathrm{mg} / \mathrm{kg})\end{array}$ & $\begin{array}{c}\text { LOI } \\
(\%)\end{array}$ \\
\hline $128-799 \mathrm{~A}-$ & & & & & & & & & & & & \\
& & & & & & & & & & & & \\
$1 \mathrm{H}$ & 16.5 & 3.36 & 0.055 & 0.399 & 7.30 & 0.344 & 0.510 & 0.0434 & 0.245 & 89.6 & 40 & 11.2 \\
$6 \mathrm{H}$ & 43.9 & 3.18 & 0.081 & 0.332 & 4.11 & 0.301 & 0.394 & 0.0370 & 0.203 & 120.3 & 56 & \\
$10 \mathrm{H}$ & 82.4 & 2.81 & 0.052 & 0.283 & 5.50 & 0.312 & 0.367 & 0.0251 & 0.166 & 66.2 & 29 & 11.4 \\
$21 \mathrm{X}$ & 190 & 2.75 & 0.028 & 0.310 & 11.16 & 0.315 & 0.395 & 0.0249 & 0.172 & 25.4 & 9 & 11.5 \\
$36 \mathrm{X}$ & 321 & 3.05 & 0.060 & 0.307 & 5.16 & 0.321 & 0.489 & 0.0114 & 0.182 & 22.1 & 9 & 11.5 \\
$51 \mathrm{X}$ & 465 & 3.25 & 0.044 & 0.287 & 6.59 & 0.343 & 0.479 & 0.0252 & 0.177 & 21.5 & 9 & 12.6 \\
\hline
\end{tabular}

Note: $\mathrm{Si} / \mathrm{Al}, \mathrm{Ca} / \mathrm{Al}, \mathrm{Mg} / \mathrm{Al}, \mathrm{Mg} / \mathrm{Ca}, \mathrm{K} / \mathrm{Al}, \mathrm{Na} / \mathrm{Al}, \mathrm{Ti} / \mathrm{Al}$, and $\mathrm{Fe} / \mathrm{Al}$ are molar ratios. 


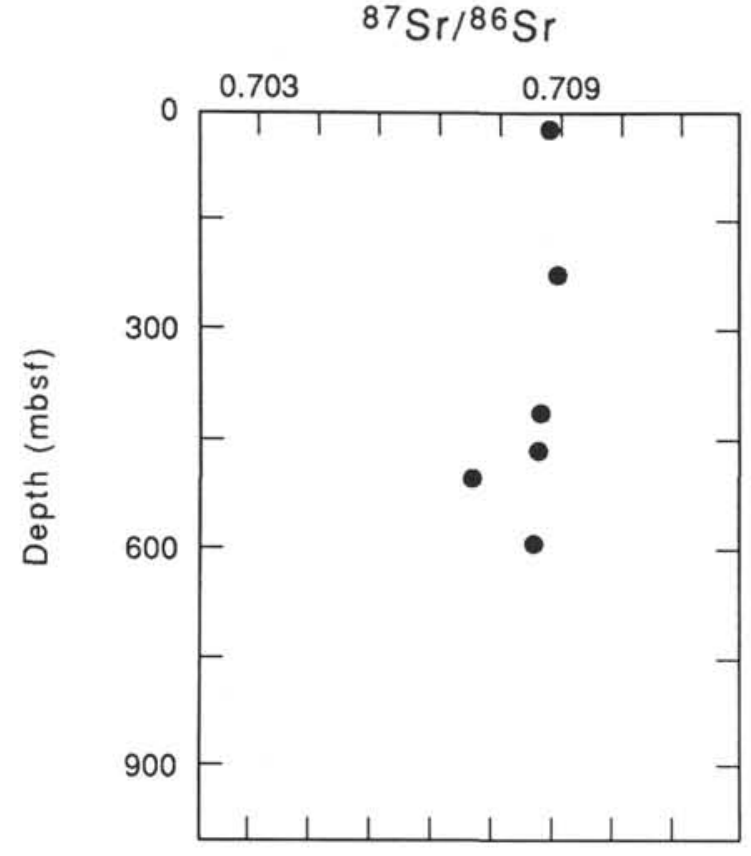

$\delta \mathrm{D}$

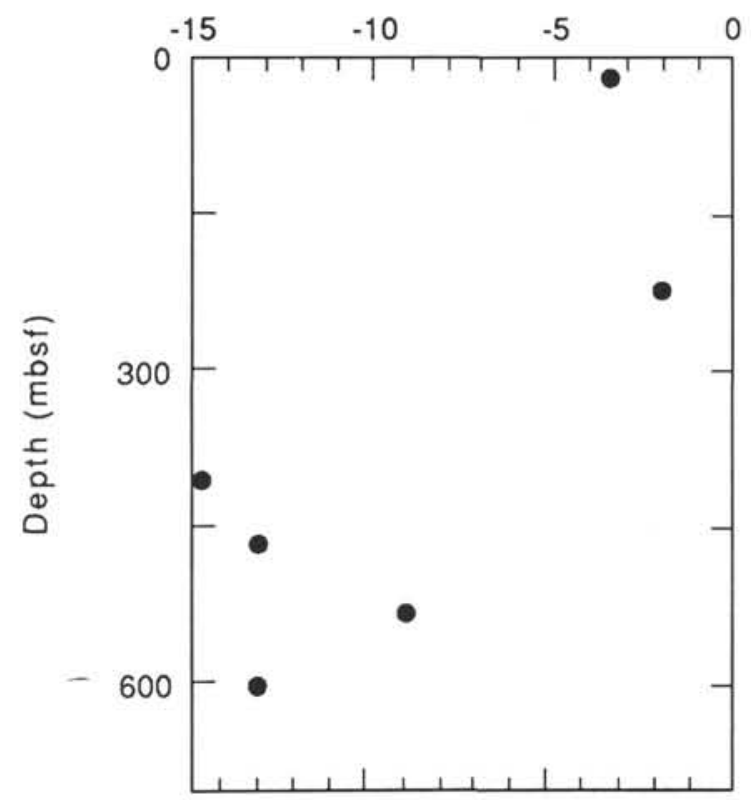

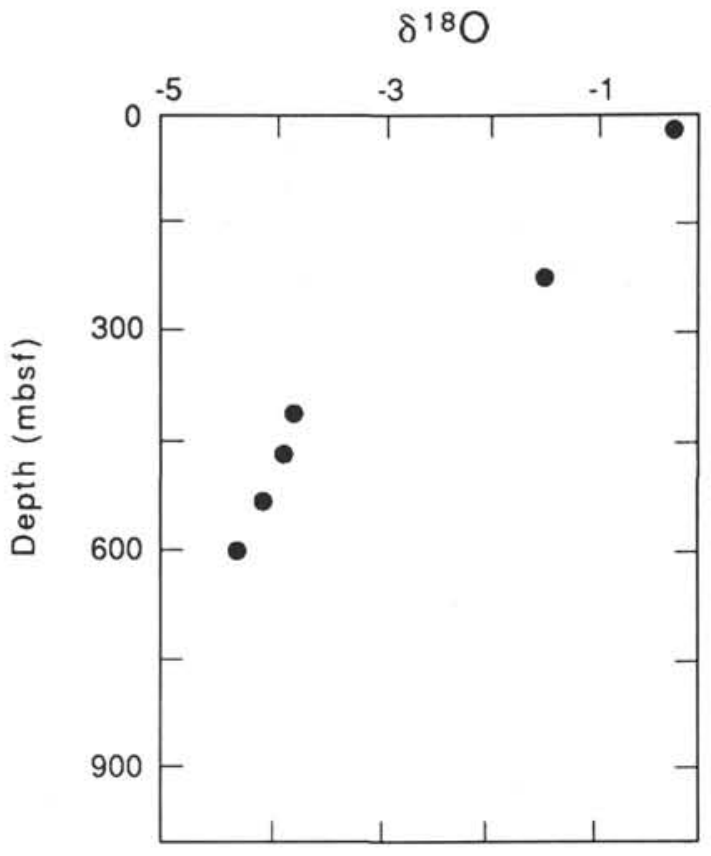

$\delta^{13} \mathrm{C}$

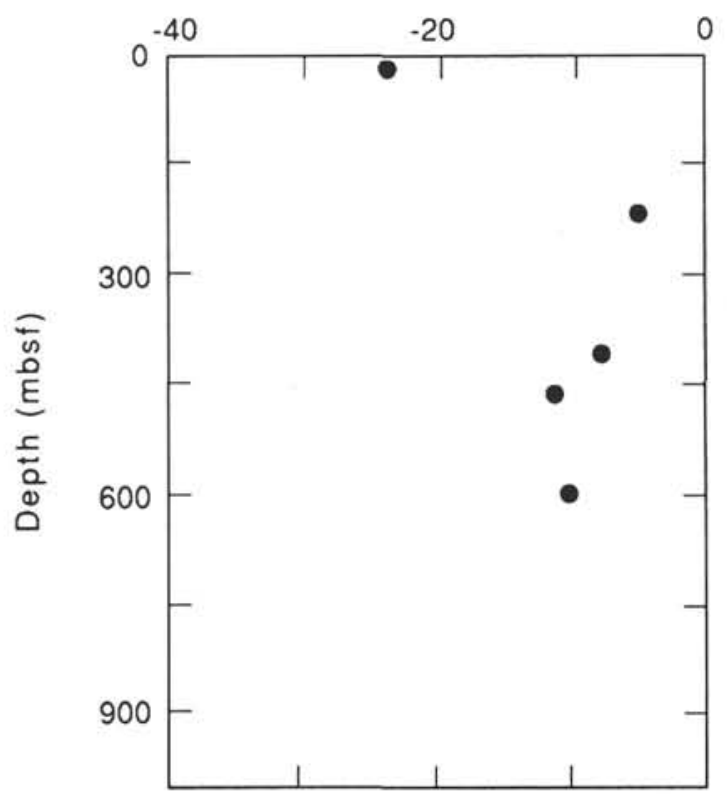

Figure 3. Interstitial water isotope composition. 
Table 6. Chemical composition of bulk sediments, Site 798 .

\begin{tabular}{|c|c|c|c|c|c|c|c|c|c|c|c|c|}
\hline Core & $\begin{array}{l}\text { Depth } \\
\text { (mbsf) }\end{array}$ & $\mathrm{Si} / \mathrm{Al}$ & $\mathrm{Ca} / \mathrm{Al}$ & $\mathrm{Mg} / \mathrm{Al}$ & $\mathrm{Mg} / \mathrm{Ca}$ & $\mathrm{K} / \mathrm{Al}$ & $\mathrm{Na} / \mathrm{Al}$ & $\mathrm{Ti} / \mathrm{Al}$ & $\mathrm{Fe} / \mathrm{Al}$ & $\underset{(\mathrm{mg} / \mathrm{kg})}{\mathrm{Zn}}$ & $\underset{(\mathrm{mg} / \mathrm{kg})}{\mathrm{Cu}}$ & $\begin{array}{l}\text { LOI } \\
(\%)\end{array}$ \\
\hline \multicolumn{13}{|c|}{ 128-798B- } \\
\hline $2 \mathrm{H}$ & 10 & 3.09 & 0.137 & 0.284 & 2.08 & 0.311 & 0.683 & 0.0312 & 0.247 & 64.3 & 26 & 13.1 \\
\hline $4 \mathrm{H}$ & 37 & 3.12 & 0.097 & 0.214 & 2.21 & 0.336 & 0.658 & 0.0313 & 0.281 & 97.5 & 43 & 14.3 \\
\hline $6 \mathrm{H}$ & 50 & 3.51 & 0.187 & 0.198 & 1.06 & 0.319 & 0.672 & 0.0232 & 0.210 & 70.9 & 33 & \\
\hline $7 \mathrm{H}$ & 60 & 3.41 & 0.192 & 0.198 & 1.03 & 0.277 & 0.598 & 0.0292 & 0.253 & 52.6 & 24 & 10.3 \\
\hline $13 \mathrm{H}$ & 118 & 3.45 & 0.181 & 0.202 & 1.12 & 0.274 & 0.571 & 0.0248 & 0.213 & 77.8 & 35 & \\
\hline $14 \mathrm{H}$ & 133 & 3.52 & 0.153 & 0.228 & 1.50 & 0.312 & 0.611 & 0.0274 & 0.241 & 39.2 & 16 & 14.2 \\
\hline $17 \mathrm{X}$ & 156 & 3.10 & 0.135 & 0.194 & 1.44 & 0.276 & 0.587 & 0.0173 & 0.158 & 27.8 & 13 & 14.9 \\
\hline $22 \mathrm{X}$ & 206 & 2.91 & 0.103 & 0.197 & 1.92 & 0.286 & 0.514 & 0.0158 & 0.157 & 21.8 & 9 & 11.2 \\
\hline $27 \mathrm{X}$ & 253 & 3.45 & 0.048 & 0.199 & 4.11 & 0.310 & 0.583 & 0.0219 & 0.216 & 20.8 & 9 & 12.5 \\
\hline $32 X$ & 301 & 2.94 & 0.029 & 0.226 & 7.81 & 0.292 & 0.555 & 0.0143 & 0.138 & 19.8 & 9 & 11.8 \\
\hline $38 \mathrm{X}$ & 358 & 2.91 & 0.015 & 0.180 & 12.09 & 0.278 & 0.442 & 0.0233 & 0.206 & 17.6 & 8 & 13.1 \\
\hline $43 X$ & 406 & 2.98 & 0.021 & 0.258 & 12.07 & 0.281 & 0.470 & 0.0268 & 0.256 & 44.9 & 19 & 11.0 \\
\hline $49 X$ & 466 & 3.00 & 0.021 & 0.232 & 11.13 & 0.272 & 0.482 & 0.0225 & 0.217 & 35.2 & 17 & 10.3 \\
\hline $53 X$ & 503 & 3.22 & 0.016 & 0.292 & 18.11 & 0.274 & 0.475 & 0.0264 & 0.303 & 22.7 & $<1$ & \\
\hline
\end{tabular}

Note: $\mathrm{Si} / \mathrm{Al}, \mathrm{Ca} / \mathrm{Al}, \mathrm{Mg} / \mathrm{Al}, \mathrm{Mg} / \mathrm{Ca}, \mathrm{K} / \mathrm{Al}, \mathrm{Na} / \mathrm{Al}, \mathrm{Ti} / \mathrm{Al}$, and $\mathrm{Fe} / \mathrm{Al}$ are molar ratios.

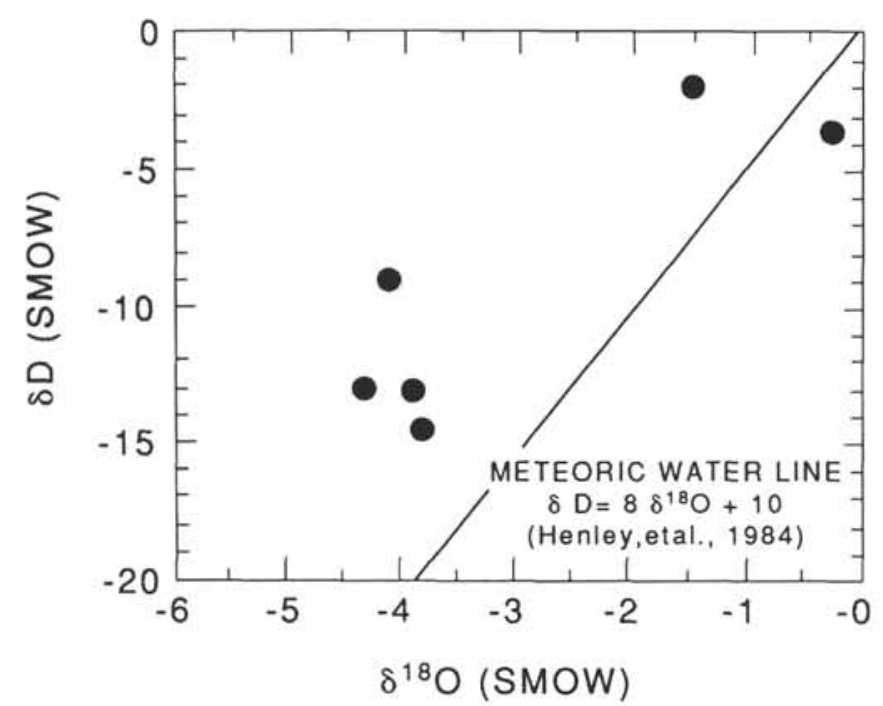

Figure 4. $\delta \mathrm{D}$ vs. $\delta^{18} \mathrm{O}$.
Table 7. Chemical composition of carbonate nodules from Site 799.

\begin{tabular}{cccccc}
\hline Core & $\begin{array}{c}\text { Depth } \\
(\mathrm{mbs})\end{array}$ & $\begin{array}{c}\mathrm{Ca} \\
(\mathrm{mmol} / \mathrm{g})\end{array}$ & $\begin{array}{c}\mathrm{Mg} \\
(\mathrm{mmol} / \mathrm{g})\end{array}$ & $\begin{array}{c}\mathrm{Fe} \\
(\mathrm{mmol} / \mathrm{g})\end{array}$ & $\begin{array}{c}\mathrm{Mn} \\
(\mathrm{mmol} / \mathrm{g})\end{array}$ \\
\hline 128-799A- & & & & & \\
$51 \mathrm{X}$ & 462 & 4.16 & 2.73 & 1.53 & 1.49 \\
$128-799 \mathrm{~B}-$ & & & & & \\
$18 \mathrm{R}$ & 610 & 3.97 & 2.92 & 1.67 & 1.33 \\
$21 \mathrm{R}$ & 638 & 3.55 & 3.06 & 1.91 & 1.74 \\
\hline
\end{tabular}



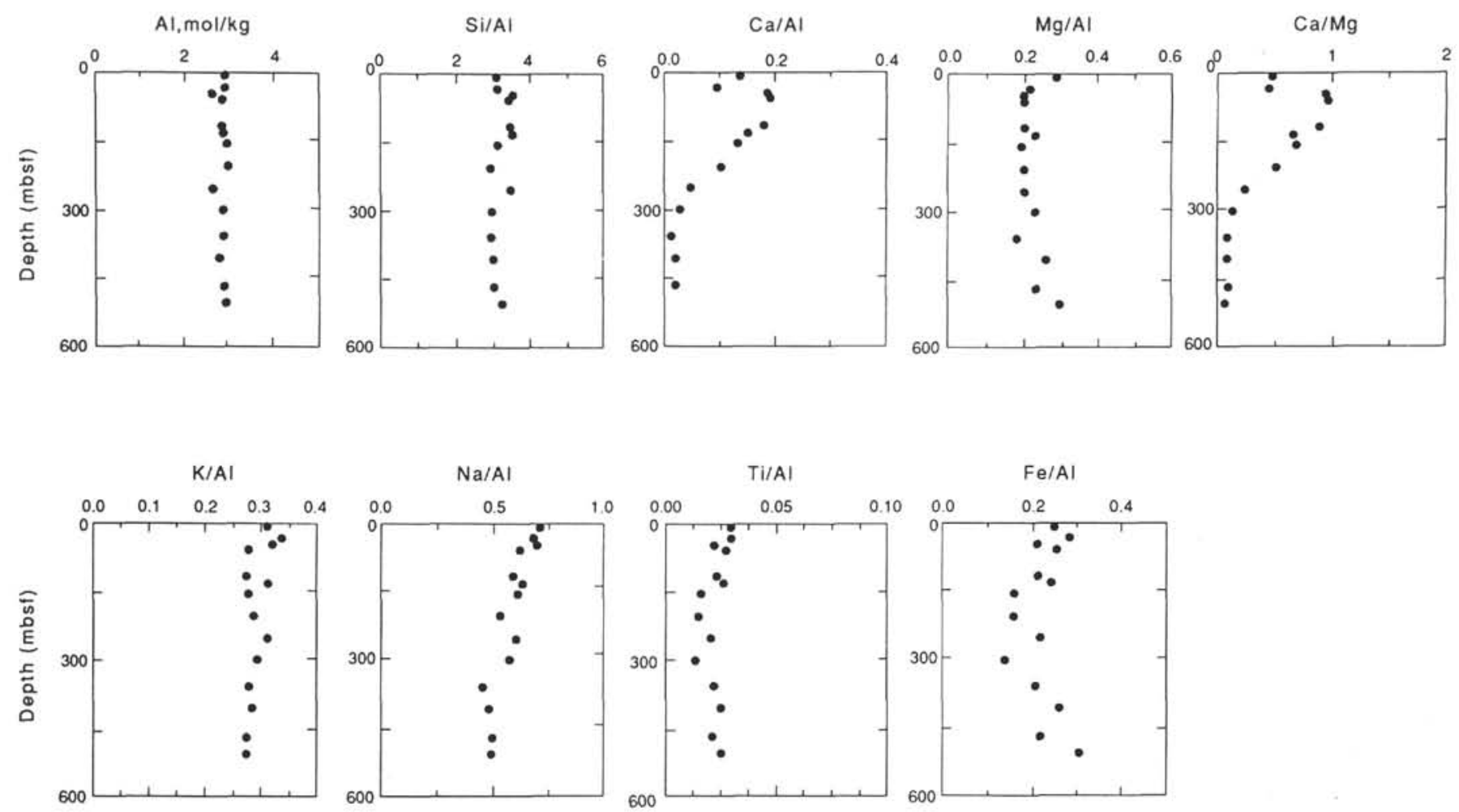

Figure 5. Bulk-sediment major element molar ratios and trace element concentrations, Site 798. 

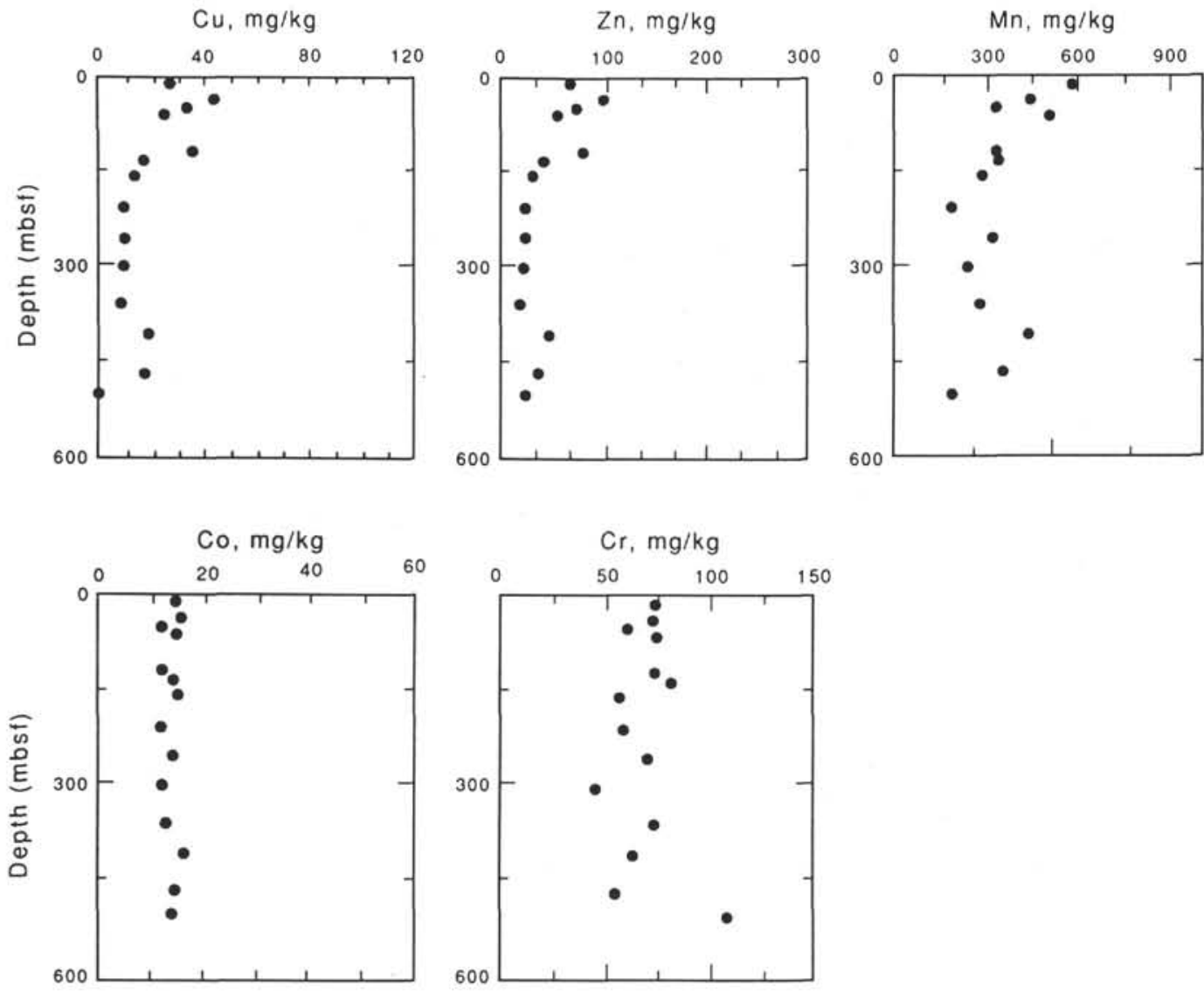

Figure 5 (continued). 
A. A. STURZ, B. B. HAMAN, G. EMANUEL

Al, $\mathrm{mol} / \mathrm{kg}$

Si/AI

$\mathrm{Ca} / \mathrm{Al}$

$\mathrm{Mg} / \mathrm{Al}$

$\mathrm{Ca} / \mathrm{Mg}$
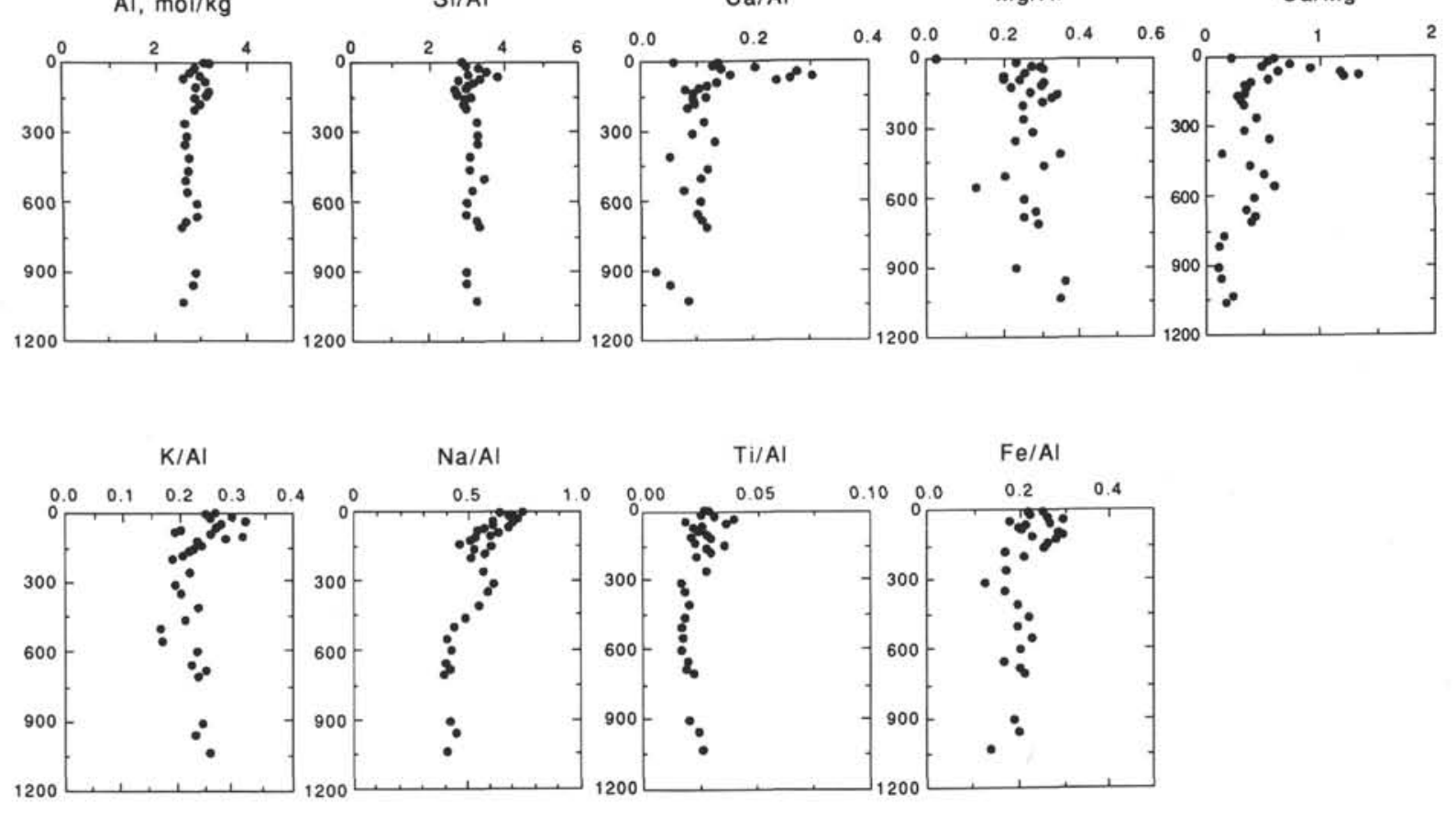

Figure 6. Bulk-sediment major element molar ratios and trace element concentrations, Site 799.

618 
$\mathrm{Cu}, \mathrm{mg} / \mathrm{kg}$

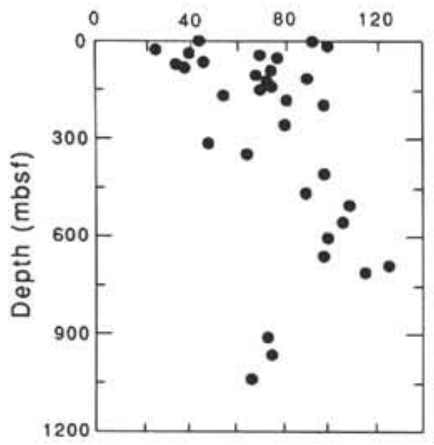

Co, $\mathrm{mg} / \mathrm{kg}$

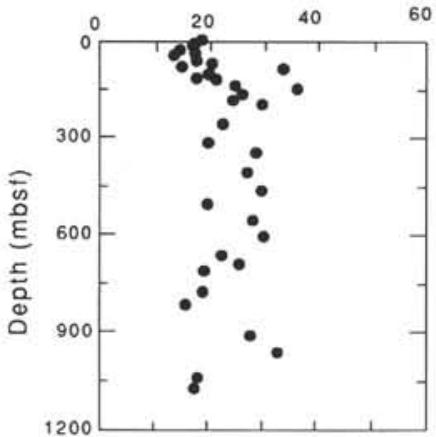

$\mathrm{Zn}, \mathrm{mg} / \mathrm{kg}$
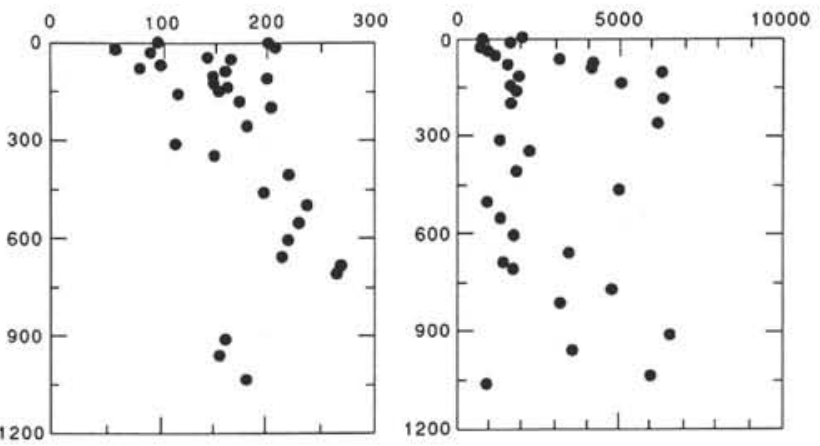

Figure 6 (continued).

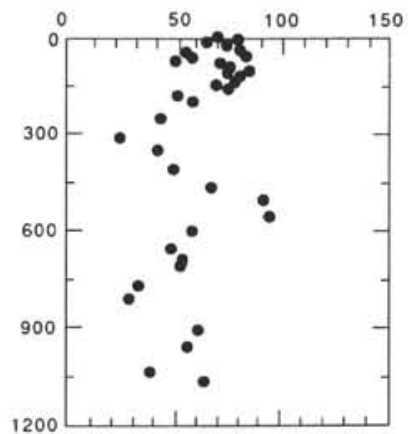



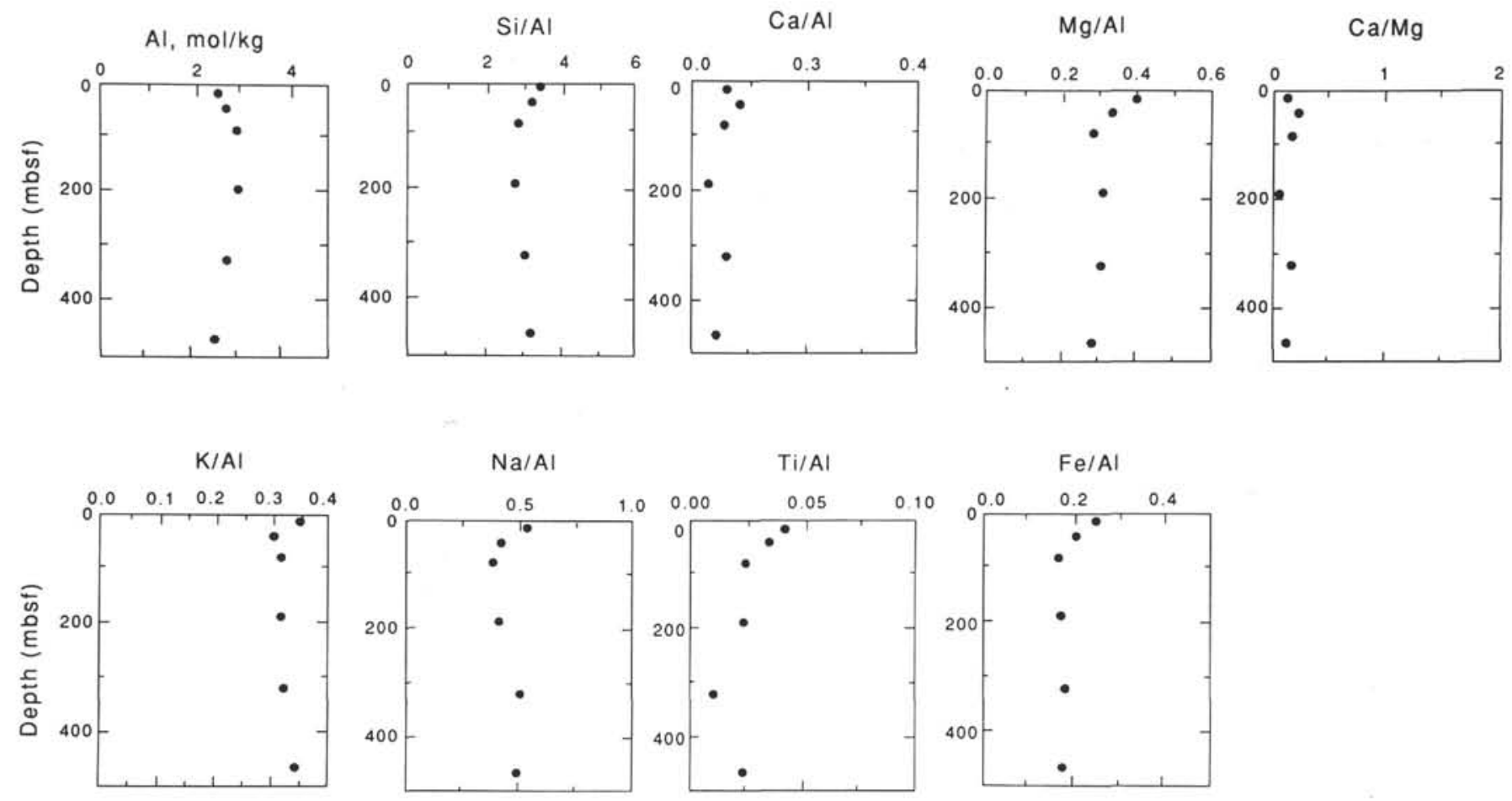

Figure 7. Clay-size-fraction major element molar ratios and trace element concentrations, Site 799. 

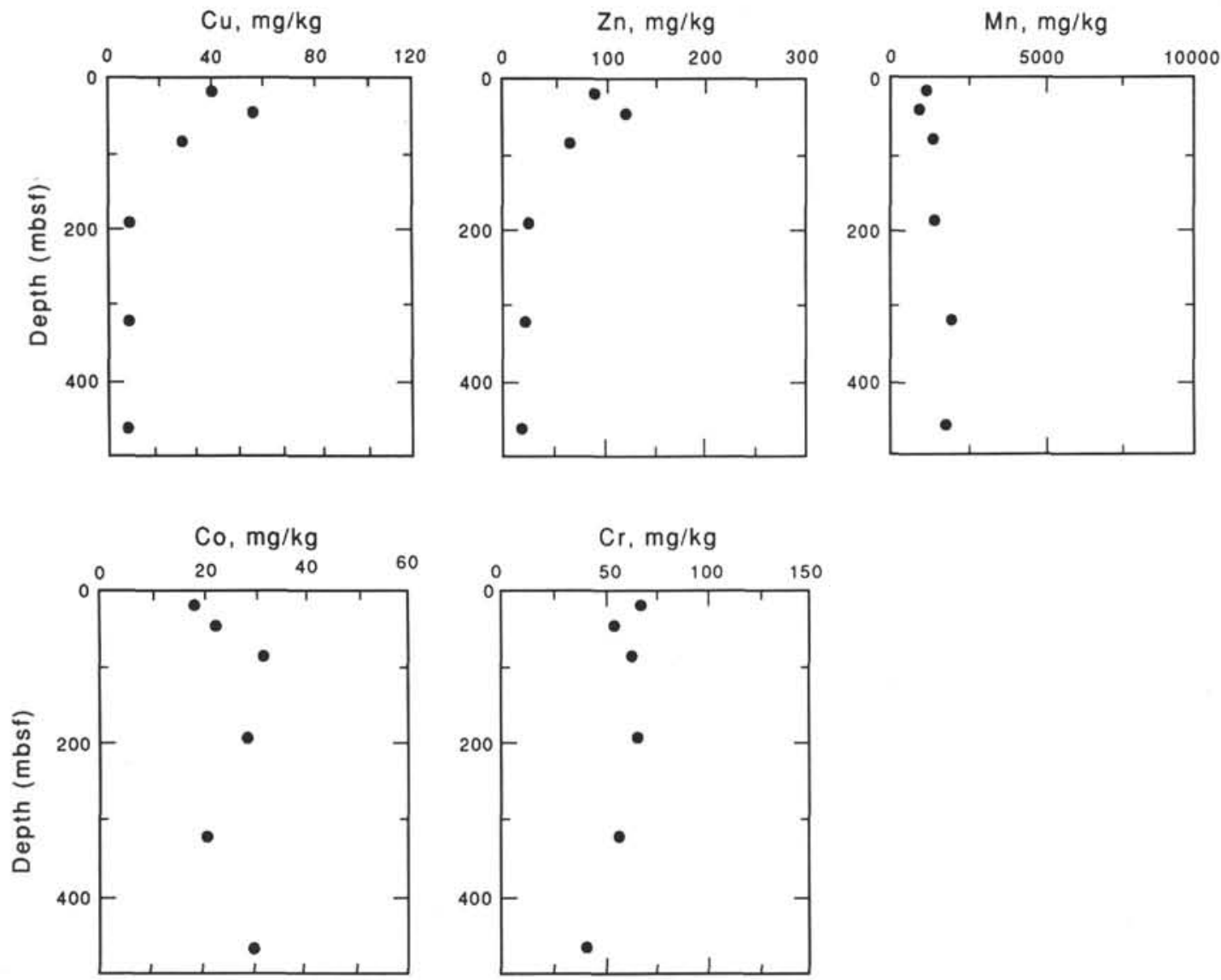

Figure 7 (continued). 